SAND75-0517

Unlimited Release

\title{
Special Closure for Radioactive Shipping Container
}

John V. Otts

Prepared by Sandia Laboratories, Albuquerque, New Mexico 87115

and Livermore, California 94550 tor the United States Atomic Energy

Commission under Contract AT (29-1)-789

Printed March 1975

\section{Sandia Laboratories}

When printing a copy of any digitized SAND Report, you are required to update the markings to current standards. 
Issued by Sandia Laboratories, operated for the United States Energy Research and Development Administration by Sandia Corporation.

\section{NOTICE}

This report was prepared as an account of work sponsored by the United States Government. Neither the United States nor the United States Energy Research and Development Administration, nor any of their employees, nor any of their contractors, subcontractors, or their employees, makes any warranty, express or implied, or assumes any legal liability or responsibility for the accuracy, completeness or usefulness of any information, apparatus, product or process disclosed, or represents that its use would not infringe privately owned rights. 
SAND75-0517

Unlimited Release

Printed March 1976

SPECIAL CLOSURE FOR RADIOACTIVE SHIPPING CONTAINER

John V. Otts

Track Guns and Hydrodynamics Division 9333

Sandia Laboratories

Albuquerque, NM 87115

\begin{abstract}
The objective of this program was to develop a special lid closure for radioactive material shipping containers, typically steel drums. Three closure techniques were designed, fabricated, and proven to be structurally adequate to protect $1000 \mathrm{lb}$ when dropped 30 feet. The three designs were (1) a 6-inch lid extension (skirt), (2) a 6-inch inner lid, and (3) c-clamps used at the container/lid interface. Based upon structural integrity, economic impact, and minimal design change, the 6 -inch lid extension is recommended.
\end{abstract}

- Printed in the United States of America

Available from

National Technical Information Service

U. S. Department of Commerce

5285 Port Royal Road

Springfield, Virginia 22161

Price: Printed Copy $\$ 5.00$; Microfiche $\$ 2.25$ 


\section{CONTENTS}

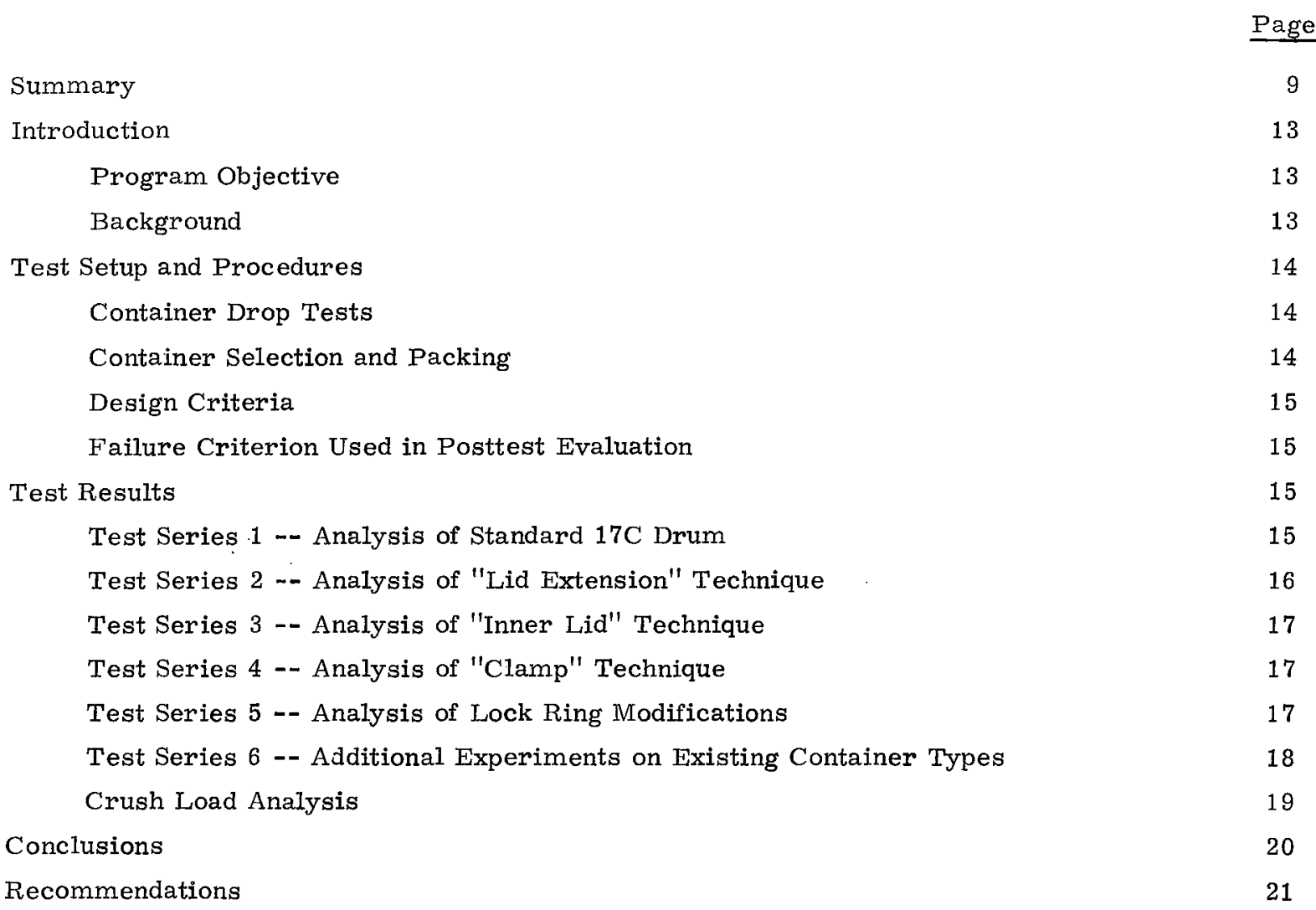

TABLES 
FIGURES

\begin{tabular}{|c|c|c|c|}
\hline Figure & & Page & \\
\hline 1 & Sandia Laboratories' Drop Tower Facility & 24 & \\
\hline 2 & Test Fixture and Impact Surface & 25 & \\
\hline 3 & Drop Height and CG Location Relative to Impact & 26 & \\
\hline $4 \mathrm{a}$ & Standard Lid and Lock Ring & 26 & \\
\hline $4 \mathrm{~b}$ & 17C Container, Celotex Packing and Inner Container & 27 & \\
\hline $4 c$ & Loading Lead Sheet Into Inner Container & 27 & \\
\hline 5 & Packed Container & 28 & \\
\hline 6 & Standard 17C Drum - Success After 625-Pound, 30-Foot Drop & 28 & \\
\hline 7 & Standard 17C Drum - Failure After 650-Pound, 30-Foot Drop & 29 & \\
\hline 8 & Standard 17C Drum - Failure After 1000-Pound, 30-Foot Drop & 29 & \\
\hline 9 & Standard 17C Drum - Bottom Impact on Seam, 1000 Pounds at 30 Feet & 30 & \\
\hline 10 & Standard 17C Drum - Bottom Impact $90^{\circ}$ from Seam, 1000 Pounds at 30 Feet & 30 & \\
\hline 11 & $\begin{array}{l}\text { Standard } 17 \mathrm{C} \text { Drum - Bottom Impact, Seam on Crush Line, } 1000 \text { Pounds } \\
\text { at } 30 \text { Feet }\end{array}$ & 31 & \\
\hline 12 & Standard Lid with 6-Inch Extension & 31 & \\
\hline 13 & Celotex Packing Inside Lid Extension & 32 & \\
\hline 14 & 6-Inch Lid Extension Technique - 1000 Pounds at 30 Feet & 32 & \\
\hline 15 & 6-Inch Lid Extension Technique - 1000 Pounds at 45 Feet & 33 & \\
\hline 16 & Attachment of 6-Inch Extension to Standard Lid & 33 & \\
\hline 17 & Inner Lid Details & 34 & \\
\hline 18 & Inner Lid with 6-Inch Skirt & 34 & \\
\hline 19 & Packing of Inner Lid with 6-Inch Skirt & 35 & \\
\hline 20 & Installation of Inner Lid with 6-Inch Skirt & 35 & \\
\hline 21 & Inner Lid Technique - 1000 Pounds at 30 Feet & 36 & \\
\hline 22 & Inner Lid Technique, Internal Seal, Same Test as in Figure 21 & 36 & \\
\hline 23 & Packing with 6-Inch Internal Lid & 37 & \\
\hline 24 & Shear of 6-Inch Internal Lid When Improperly Packed & 37 & \\
\hline 25 & Details of 6 -Inch Internal Lid & 38 & $\cdot$ \\
\hline 26 & C-Clamp Without Lock Ring & 38 & \\
\hline 27 & C-Clamp With Lock Ring & 38 & , \\
\hline 28 & Posttest on $12 \mathrm{C}$-Clamps and No Lock Ring - 950 Pounds at 30 Feet & 39 & \\
\hline 29 & Posttest on $6 \mathrm{C}$-Clamps with Lock Ring - 1000 Pounds at 30 Feet & 39 & \\
\hline 30 & Clips Welded to Lock Ring & 40 & \\
\hline 31 & Extension of Lock Ring & 40 & \\
\hline
\end{tabular}


FIGURES (cont)

\begin{tabular}{|c|c|c|}
\hline Figure & & Page \\
\hline 32 & Posttest - 6 Clips Welded to Lock Ring - 800 Pounds at 30 Feet & 40 \\
\hline 33 & Details of Top and Bottom Clips Welded to Lock Ring & 41 \\
\hline 34 & Pass with 8 Clips, Top and Bottom - 800 Pounds at 30 Feet & 42 \\
\hline 35 & Marginal Pass with 8 Clips, Top and Bottom - 800 Pounds at 30 Feet & 42 \\
\hline 36 & Half Ring Design & 43 \\
\hline 37 & Sketch of Harry Fine Technique & 43 \\
\hline 38 & Posttest on Harry Fine Technique - 1000 Pounds at 30 Feet & 44 \\
\hline 39 & Posttest on MS-27683-14 Container - 600 Pounds at 30 Feet & 44 \\
\hline 40 & Container Load Configuration and Crush Test Simulation & 45 \\
\hline 41 & Crush Test Setup & 46 \\
\hline 42 & Failure of $17 \mathrm{C}$ Container Lid at 110,000 Pounds Static Load - Test 1 & 46 \\
\hline 43 & Failure of $17 \mathrm{C}$ Container Bottom at 120,000 Pounds Static Load - Test 2 & 47 \\
\hline 44 & External View of Closure at 125,000 Pounds - Test 2 & 47 \\
\hline 45 & Internal View of Closure at 125,000 Pounds - Test 2 & 48 \\
\hline 46 & Failure of Closure at 105,000 Pounds - Test 3 & 48 \\
\hline 47 & Failure of $17 \mathrm{C}$ Container Bottom at 120,000 Pounds - Test 4 & 49 \\
\hline 48 & External View of Closure at 125,000 Pounds - Test 4 & 49 \\
\hline 49 & Internal View of Closure at 125,000 Pounds - Test 4 & 50 \\
\hline
\end{tabular}


Summary

The objective of this program was to develop a special lid closure for radioactive material shipping containers. Radioactive materials are transported by ERDA in commercial drums which typically range in size from 16 to 100 gallons. The drums and their covers are constructed of nominal 18-gauge steel. Further, the cover is secured to the container by a 12-gauge ring and closure bolt. An inner shipping container is packed into the drum using Celotex between this inner container and the drum to provide the necessary protection against impact and thermal damage. The inner shipping container is designed to provide primary and/or secondary containment of the radioactive material.

Certification of these containers by ERDA for use in the transportation of radioactive materials requires that each drum design survive the requirements set forth in AECM-0529. In particular, the loaded drum must survive a 30-foot drop onto a flat, unyielding surface where the impact orientation is that producing the highest probability of damage. Subsequent to the 30-foot drop, the loaded drum is exposed to a $1475^{\circ} \mathrm{F}$ fire for a period of 30 minutes. The drum is certified if the internal shipping container and the packing material are not damaged by the impact/fire environment. This is assured if the drum and cover remain sealed to prevent burning of the packing material.

Experimental results have shown that the present container has the necessary structural integrity against the environmental test requirements, but the lid closure is marginal. More specifically, the lid closure fails to maintain a tight seal between the container and the lid after drop tests, thus causing the inner container to be vulnerable to fire. This observation by ERDA prompted the request for a special lid closure. Further, ERDA specified that the new closure should: (1) be as strong and resistant to a drop as the bottom of the container, (2) have minimal economic impact on the overall container cost, (3) maximize the use of existing container design, and (4) consider crush loads.

The program consisted of the following basic phases: (1) the test facility, test procedure, and test container were selected; (2) the basic failure criteria were analyzed through experimental drops; (3) new closures were designed and tested; and (4) the designs were evaluated in terms of effectiveness, economics, and convenience.

The test facility selected was Sandia Laboratories' drop tower located on Kirtland AFB, Albuquerque, New Mexico. The test setup allowed control of the test container orientation. In addition, the container was guided during drop to within 5 feet of the impact surface and explosive cutters were activated to free the container for impact onto a 4-inch steel plate resting on a 1 foot thick slab of concrete. 
A 55-gallon type 17C commercial container with lid and lock ring was selected as the container most representative of those used in the field. Consequently, this container, packed with Celotex and a "variable weight" inner container, was used throughout the program. The inner container was designed to accept weights from 0 to 770 pounds, giving an overall weight range from 230 to 1000 pounds. Packing and sealing of the containers was done according to standard procedures to insure consistency.

A failure criterion was established whereby any visual exposure of the Celotex packing material was classified as a failure during a fire test. This was necessary since a fire test on each container was not feasible. Therefore, each container was dropped from 30 feet and, after impact, was visually inspected, photographed, and stored for future reference.

The first series of tests established the following:

(1) The standard $17 \mathrm{C}$ container repeatedly fails when the total container weight exceeds 600 pounds;

(2) The lock ring fails to hold the lid to the container and is therefore considered the weakest link in the container and lid combination;

(3) The container bottom and walls tested successfully up to 1000 pounds total minimum weight (weight in excess of 1000 pounds was not tested); and

(4) The drop forged lock ring and bolt (previously designed and developed by Sandia) did not fail during the test series.

Based upon the above results, a design goal was set whereby the closure would protect up to 1000 pounds total weight when dropped 30 feet. The 1000 pound weight was established because a 55-gallon container could not possibly exceed this weight if it were packed to standard specifications.

Three new closure techniques were designed, fabricated, and proven to be structurally adequate to protect 1000 pounds when dropped 30 feet. The three designs were (1) a six-inch lid extension (skirt), (2) a six-inch inner lid, and (3) c-clamps used at the container/lid interface. Each technique is fully described in the text of the report.

Several alternate techniques also were evaluated and found to be more effective than the standard closure on the $17 \mathrm{C}$ container. However, since these alternate techniques failed to protect up to a 1000 pound weight, they are not included in this summary; they are discussed in the text of the report. 
Crush tests were run on the standard $17 \mathrm{C}$ container with a standard lid closure, the c-clamp closure, the six-inch lid extension, and the six-inch inner lid. The following were observed:

(1) A static weight of 110,000 pounds caused the standard lid and the c-clamp closure to fail;

(2) A static weight of 120,000 pounds caused the container bottom to fail; and

(3) The 6-inch lid extension and 6-inch inner lid protected beyond 120, 000 pounds.

Based upon structural integrity, economic impact, and minimal design change, the six-inch lid extension is recommended over the other techniques. (Note: Patent application has been made on each of the three techniques described above.)

Lastly, a container closure technique patented and manufactured by H. Fine Associates, Inc., was evaluated and found to strengthen the closure to a container weight of 1000 pounds. However, Mr. Fine failed to supply sufficient information concerning cost and installation procedures, thereby preventing any systematic comparison with the Sandia "in-house" techniques. 
SPECIAL CLOSURE FOR RADIOACTIVE SHIPPING CONTAINER

Introduction

The work reported here was performed under Program 189/ALO 415C. The work was supported by the Production Division of the Energy Research and Development Administration (ERDA). Mr. J. Sisler was the ERDA program administrator.

Program Objective

The program objective was to develop a special closure for radioactive material shipping containers. The new closure should: (1) be as strong as the bottom of the container, (2) have minimal economic impact, (3) maximize the use of existing containers without redesign, and (4) consider crush loads.

$\underline{\text { Background }}$

Commercial drums, typically ranging in size from 16 to 100 gallons, are used by ERDA to transport radioactive material. An inner shipping container, which provides primary and/or secondary containment of radioactive materials, is packed within the steel drum. The packing between the inner container and outer drum is an insulation material which provides the internal container with thermal and impact protection.

The structural integrity of the drum lid closure has been of particular concern for some time. Certification by ERDA for use in transportation requires that the drum design survive requirements set forth in AECM-0529. In particular, the drum must protect the inner container from a 30 minute exposure to a $1475^{\circ} \mathrm{F}$ fire after the complete assembly has been dropped 30 feet onto a flat, unyielding surface. The impact orientation is further specified as that producing the highest probability of damage.

For each type of drum there is a critical "package weight" beyond which the lid closure consistently fails for a 30 foot drop, thus exposing the internal packing and/or container to fire. The new closure design would increase the "package weight" capability of each type container and be relatively free of operator error and/or neglect during assembly. Ideally, the new closure would be at least as strong as the bottom of the drum, have minimal economic impact, and allow maximum use of existing containers without redesign. 
Test Setup and Procedures

Container Drop Tests

All container drop tests were performed at Sandia Laboratories' drop tower facility (Figure 1). The test fixture (Figure 2) was designed to allow control of the container's impact orientation. The container was guided during its fall to within 5 feet of the impact surface where it was released by explosive bolt cutters and allowed to free fall the remaining distance to impact. The impact surface (Figure 2) consisted of a 4-inch thick steel plate resting on a one-foot thick slab of concrete.

The drop height was that measured between the lowest point on the container and the impact surface. In addition, the center-of-gravity (CG) of the loaded container was aligned directly above the point of initial impact (Figure 3); impact attitude was not a variable in these tests. Each drop test was photographed using two Fastax (4000 frames/second) and one Milliken (400 frames/second) cameras. Finally, posttest photos were taken to document the condition of the container.

Container Selection and Packing

Subsequent to a literature review and discussions with personnel associated with shipping containers, the following drum, packing, and internal container were selected as the most representative types for this development program.

\begin{tabular}{|c|c|}
\hline Drum & $\begin{array}{l}\text { Type } 17 \mathrm{C}, 55 \text { gallon capacity, } 18 \text { gauge wall, } 16 \text { gauge } \\
\text { lid, ID }=22-1 / 2 \mathrm{inch} \pm 1 / 16, \mathrm{H}=33-7 / 32 \mathrm{inch} \pm 1 / 8 . \\
\text { Purchased from Bennett Industries, Peotone, Ill. }\end{array}$ \\
\hline Lock Ring & 12 gauge, drop forged, $5 / 8$ inch bolt. \\
\hline Packing & $\begin{array}{l}\text { Celotex discs no less than } 1 / 2 \text { inch thick. Purchased } \\
\text { from DuroFlex Products Company, Foristell, Mo. }\end{array}$ \\
\hline Felted Insulation & $\begin{array}{l}1 / 2 \text { inch Cerafelt below lid. Purchased from Triple I } \\
\text { Company, Phoenix, Ariz. }\end{array}$ \\
\hline Inner Container & $\begin{array}{l}\mathrm{OD}=10-1 / 2 \mathrm{inch}, \mathrm{H}=25 \mathrm{inch}, \mathrm{T}=1 / 4 \mathrm{inch} \text {, steel } \\
\text { with all external edges rounded. }\end{array}$ \\
\hline $\begin{array}{l}\text { Inner Container } \\
\text { Weight }\end{array}$ & Lead sheet \\
\hline
\end{tabular}


The weight breakdown was as follows; test weights include fixed plus variable weight throughout this report.

\begin{tabular}{|c|c|c|}
\hline Drum, Lid, Ring & $\approx 50$ & \\
\hline Packing & $\approx 100$ & Fixed for each drop test \\
\hline Inner Container (empty) & $\approx 80$ & \\
\hline Variable Weight & $\approx 0$ to & 0 - Varied \\
\hline Maximum & $\approx 1000$ & ounds \\
\hline
\end{tabular}

Figures $4 a, 4 b$, and $4 c$ depict the various components used in the container evaluation tests.

Packing procedures were consistent with recommendations; the packing material was "tight fit" under the container lid, the lock ring was torqued to $40 \mathrm{ft}-\mathrm{lb}$, and a soft hammer was used to tap around the periphery of the ring. As recommended by E. E. Lewallen of DuPont/SRL, the minimum insulation thickness between the inner and outer containers was 6 inches at the walls and 4 inches at the ends. (Figure 5).

$\underline{\text { Design Criteria }}$

Using the packing tolerances specified by Lewallen, it was inconceivable that a 55 gallon drum could weigh more than 1000 pounds since this was the maximum weight with the inner container full of lead. Therefore, a 1000 pound weight was selected as the maximum for protection from closure failure.

\section{Failure Criterion Used in Posttest Evaluation}

A fire test on each container was not feasible for both economic and manpower reasons. Therefore, posttest results were based on the following: any visual exposure of the Celotex packing material was classified as a failure, with respect to fire test integrity.

\section{Test Results}

\section{Test Series 1 -- Analysis of Standard 17C Drum}

The first series of drop tests was conducted to: (1) determine the maximum weight capability of a standard 17C drum closure, (2) confirm that the lid/drum interface, supported by the lock ring, was the weakest portion of the container, (3) determine the weight capability of the container bottom, and (4) obtain photographic coverage of typical failures for further analysis. 
The standard 17C drum, with lock ring, fails above 600 pounds total weight. Test results consisted of two successful tests at approximately 600 pounds, two failures at 1000 pounds, two failures at 700 pounds, and two failures at 655 pounds. All of the above drops were guided so as to impact on the lug/bolt section of the lock ring. Also, the CG of the container was directly in line above the impact point. Typical posttest results are shown in Figures 6, 7, and 8. Figure 6 shows a 625 pound, 30 foot drop which passed; Figure 7 shows a 650 pound, 30 foot drop which failed; Figure 8 shows a 1000 pound, 30 foot drop which failed.

As shown in Figures 7 and 8, a standard 17C drum failure consists of the lock ring and lid shearing past the barrel curl. The force of the impact causes the lid to bend, thus causing separation at 90 degrees, clockwise and counterclockwise, from the point of impact.

Experience throughout the test program has shown that the primary failure in the standard $17 \mathrm{C}$ drum is lock ring/lid shear from the barrel curl (Figures 7 and 8 ) and the secondary failure is lid shear from the lock ring/barrel curl assembly. If one adequately protects against the primary failure, the second will occur with very little gain in barrel weight capability (demonstrated later). Experience has also shown that the bolt and drop forged lug do not fail even with direct impact. Out of 53 drops, one lug failed. However, this one failure was predicted based upon a poor weld between the lock ring and drop forged lug.

Four tests were conducted to determine the strength of the standard 17C container bottom. These tests demonstrated that the bottom portion can survive a direct impact of at least 1000 pounds; survival at higher weights was not evaluated. The first two tests were oriented for impact on the barrel seam (Figure 9), the third test impacted 90 degrees from the seam (Figure 10), and the fourth was impacted so the seam lined up with the barrel crush line (Figure 11).

Test Series 2 - Analysis of "Lid Extension" Technique

Basically, this technique concedes that lid separation will occur above 600 pounds but protects in spite of the failure. Figure 12 shows a 6 -inch lid extension. The 6-inch skirt slips into the container and the packing is internal to this skirt (Figure 13). The lid is mounted on the barrel in the same manner as with the standard container. Five 30 foot drops at a 1000 pound container weight all passed. Further, one 45 foot drop at a 1000 pound container weight passed. The latter test is the energy equivalent of a 30 foot drop at 1500 pounds. Typical results for the 30 foot/1000 pound and 45 foot/1000 pound tests are shown in Figures 14 and 15, respectively. As shown, the lock ring/lid configuration separated 180 degrees from the impact point. However, the 6-inch lid extension maintains a tight seal within the barrel, thus protecting against fire. A standard lid can be adapted to this configuration by simply welding the 6 -inch, 16-gauge lid extension to the lid (Figure 16). Continuous weld or spot weld both proved to have adequate structural integrity against failure of the weld joint. 
Test Series 3 -- Analysis of "Inner Lid" Technique

As with the lid extension technique discussed above, the inner lid technique concedes lid separation above a 600 pound weight but continues to protect the internal packing against fire. The inner lid is shown fitted into the container in Figure 17. Figure 18 shows the 6-inch inner lid, Figure 19 shows the packing being placed inside the inner lid, and Figure 20 shows the inner lid ready for installation.

Tests established that a 2-inch inner lid was inadequate, a 4-inch inner lid would protect to a maximum of 975 pounds, and a 6-inch inner lid would protect beyond 1000 pounds (the upper limit was not established). Typical results are shown in Figures 21 and 22; the latter figure shows the seal from inside the barrel. The optimum packing with the internal lid consists of a minimum of 3 inches of Celotex between the container lid and inner lid and a minimum of 3 inches of Celotex between the inner lid and the inner container (Figure 23). This configuration was found to provide maximum protection against the inner container shearing the top of the inner lid at impact. This shear effect is depicted in Figure 24 where the packing was not optimized as specified above. As shown in Figure 25, the joint between the 6-inch inner lid skirt and the top can be either a rolled seam or a continuous weld. Both techniques were found to be structurally adequate. It should also be noted from Figure 25 that some sort of handle or other lifting device is convenient to remove the inner lid from the container.

Test Series 4 -- Analysis of "Clamp" Technique

This technique protects against lid separation from the drum. The specific type c-clamp is immaterial as long as it grips the lid and barrel curl either with (Figure 26) or without (Figure 27) the lock ring. Twelve c-clamps, equally spaced around the lid/barrel interface, successfully protected a 1000 pound (maximum) container without a lock ring. A typical posttest container is shown in Figure 28 following a 30 foot drop at 950 pounds. Six c-clamps, equally spaced, protected a 1000 pound (minimum) container with a locking ring; a typical result of a 30 foot drop at 1000 pounds is shown in Figure 29.

The use of 6 c-clamps and 12 c-clamps on containers with and without a lock ring, respectively, represents a "minimum" solution in that this concept could be carried to the extreme by use of a continuum of clamps around the periphery of the container. However, the minimum number of c-clamps is advantageous from the standpoint of cost and simplicity of assembly.

Test Series 5 -- Analysis of Lock Ring Modifications

The weakest link in the standard closure design was previously defined as shear of the lock ring/lid assembly past the barrel curl. Either adding six clips to the underside of the lock ring 
(Figure 30) or extending the lock ring down the barrel (Figure 31) increased the container capability to 700 pounds. Above 700 pounds, the lock ring grips the barrel curl but the lid shears from beneath the lock ring (Figure 32). The next attempt included eight clips welded to both top and bottom of the lock ring and alternately spaced (Figure 33). With two successes and two marginal successes out of four drops at 800 pounds, it was concluded this technique would consistently protect up to 750 pounds maximum. A success and a failure are depicted in Figures 34 and 35 , respectively. Alternate spacing of the clips was found to have a slight advantage over nonalternate spacing.

It is felt that the number of clips could be increased on the top and bottom of the lock ring to the extent that 1000 pound loads would pass. However, this was not pursued due to time, cost, and the inherent awkwardness of mounting this type of ring.

As concerns mounting the lock ring with clips, a half ring (Figure 36) was designed and evaluated. It was found that the half ring does not reduce the structural integrity provided by the full ring, but does simplify the mounting.

Test Series 6 -- Additional Experiments on Existing Container Types

Harry Fine of Harry Fine Associates, Inc., Long Island, New York, was contacted regarding a container closure designed and patented by his company. Basically, the closure consists of a standard lock ring with a 2-inch extension down the side of the container (Figure 37). The uniqueness of this closure is the rubber gasket that fits tightly over the lid/container interface and is compressed by the lock ring upon installation. This concept was tested to a load of 1000 pounds without failure (two tests). A posttest view of the container is shown in Figure 38. Based upon the experience gained throughout this program, it is felt that the "Fine" concept owes its success to the fact that the compressed rubber gasket sufficiently increases the friction coefficient between the lid barrel curl and the lock ring so as to prevent separation. Further, the fact that the "Fine" technique prevents the lid and lock ring from shearing past the barrel curl is due to both the rubber gasket (increased friction coefficient) and the lock ring extension down the side of the barrel. It should be noted that installation of the lock ring over the rubber gasket was relatively difficult using the loading technique used throughout this test series.

As a matter of interest, two MS27363-14 containers (57 gallon) with drop forged lugs and 5/8 inch bolts were purchased and evaluated. As shown in Figure 39, the containers totally failed at 800 pounds and 600 pounds. Failure of this severity, where the lock ring/lid was completely pushed off by the internal weight, was never experienced with the commercial $17 \mathrm{C}$ containers. The capability of this container was not further evaluated.

Several attempts were made to improve the $17 \mathrm{C}$ lock ring design by reshaping its cross section to allow a more efficient grip over the lid and under the barrel curl. These modifications gave 
only minimal improvement in weight capability. It was finally concluded that the lock ring, as presently fabricated throughout the industry (rolled), could not be significantly improved compared with the additional cost.

Increased access time to the inner container was originally considered to be important (but secondary) in the lid closure design. However, this concern was dismissed when it was found that the $17 \mathrm{C}$ container could be cut in half (around the periphery) in less than 2 minutes using a propane cutting torch. This was the technique used by technicians in removing the inner weight from the damaged containers.

Crush Load Analysis

Crush loads are suspected as being a severe problem, perhaps comparable to the accident environments specified in AECM-0529. Therefore, four containers were subjected to a crush test:

(1) Standard $17 \mathrm{C}$ container

(2) $17 \mathrm{C}$ container with a 6 -inch lid extension

(3) $17 \mathrm{C}$ container with 6 c-clamps over the lock ring, and

(4) $17 \mathrm{C}$ container with a 6 -inch internal lid.

Containers, when loaded in a trailer, would be in contact as shown in Figure 40 . It was assumed that a truck/trailer accident would likely cause a crush load to be applied as shown in Figure 40. Therefore, the test setup (Figure 41) consisted of laying the container on its side, using an aluminum plate to distribute the load over the container, and applying a static load until the container experienced some form of structural failure. Deflections and structural reactions were recorded at intermediate loads. (Note: Container failure was again defined as that point where the internal packing became exposed and vulnerable to fire damage.)

Test \#1 -- Standard 17C Container with Standard Lock Ring -- The load/deflection results and structural reactions are included in Table IA. The lid closure failed (Figure 42) at 110,000 pounds while the container remained structurally sound.

Test \#2 -- 17C Containers with 6-inch Lid Extension -- The results are included in Table IB. The lid closure survived beyond failure of the container bottom (120,000 pounds). The failure mode is shown in Figure 43. The structural condition of the lid closure following the bottom failure is shown in Figures 44 and 45.

Test \#3 -- 17C Container with $6 \mathrm{C}$-Clamps Over Lock Ring -- The results are included in Table IC. Within experimental accuracy, the modified lid failed at the same load (105, 000 pounds) as the standard $17 \mathrm{C}$ container closure. Failure is shown in Figure 46. 
Test \#4 - 17C Container with 6-inch Internal Lid -- The results are included in Table ID. The lid closure survived beyond failure of the container bottom (120,000 pounds). The failure of the container is depicted in Figure 47. The structural condition of the lid closure following failure of the bottom is shown in Figures 48 and 49 .

Summary -- Summarizing the crush load results, it was found that the $17 \mathrm{C}$ container will fail, as loaded, at approximately 110,000 pounds. Failure occurs at the lid closure. The 17C container with 6 c-clamps over the lock ring fails at 105, 000 pounds, thus showing no improvement. However, the $17 \mathrm{C}$ container with either the 6-inch lid extension or the 6-inch inner lid remains structurally intact up to 120,000 pounds. At this load, the container bottom fails while the closure retains its integrity against fire.

\section{Conclusions}

The following conclusions were reached as a result of this study.

(1) The critical container weight of a standard $17 \mathrm{C}$ closure is 600 pounds.

(2) The critical container weight of a standard 17C container, neglecting closure, is a minimum of 1000 pounds.

(3) The "six-inch lid extension" technique strengthens the 17C closure to a critical container weight of 1500 pounds minimum.

(4) The "six-inch internal lid" technique strengthens the $17 \mathrm{C}$ closure to a critical container weight of 1000 pounds minimum. A four-inch internal lid protects to 1000 pounds maximum.

(5) The "c-clamp" technique strengthens the 17C closure to:

(a) 1000 pounds minimum with six c-clamps over lock ring, and

(b) 950 pounds maximum with $12 \mathrm{c}$-clamps and no lock ring.

(6) The "clip" technique, using eight clips on the top and bottom of the lock ring, strengthens the closure to 800 pounds maximum. The technique was not pursued beyond this point.

(7) The closure manufactured by Harry Fine Associates, Inc., strengthens the 17C closure to a critical container weight of 1000 pounds minimum. 
(8) The $17 \mathrm{C}$ lid closure fails a crush test at 110,000 pounds static load, while the $17 \mathrm{C}$ container bottom fails at 120,000 pounds.

(9) Both the "six-inch lid extension" and "six-inch internal lid" techniques extend the $17 \mathrm{C}$ closure failure beyond the container bottom capability of 120,000 pounds static load.

(10) Using six c-clamps and lock ring, the "c-clamp" technique fails to improve the normal lid closure crush limit of 110,000 pounds.

\section{Recommendations}

Four closure techniques have proven more than adequate in meeting the specified criteria of structural integrity, economics, and minimum design impact. However, as shown in Table II, the 6 -inch lid extension offers a distinct advantage over the other designs. Therefore, it is recommended that a 6-inch lid extension be strongly considered. Estimated costs of the various techniques are included in Table III.

Should a stronger closure ever be required, any combination of the four basic concepts could be evaluated. 
TABLE I

Crush Test Results

(A) Standard 17C Container

\begin{tabular}{|c|c|c|c|}
\hline \multirow{2}{*}{$\begin{array}{l}\text { Applied } \\
\text { Load (lb) }\end{array}$} & \multicolumn{2}{|c|}{ Height (inches) } & \multirow[b]{2}{*}{ Comments } \\
\hline & Top & Bottom & \\
\hline 0 & 24 & $23-5 / 8$ & \\
\hline 40,000 & $23-1 / 8$ & $21-3 / 8$ & \\
\hline 80,000 & $22-1 / 4$ & 21 & Lid buckling at load point. \\
\hline 100,000 & $21-3 / 4$ & $20-1 / 4$ & Lid buckling across horizontal center line. \\
\hline 110,000 & $21-1 / 4$ & 20 & Failure (Figure 42). \\
\hline
\end{tabular}

(B) 17C Container with 6-inch Lid Extension

\begin{tabular}{|c|c|c|c|}
\hline 0 & 24 & $23-5 / 8$ & \\
\hline 40,000 & 23 & $21-3 / 4$ & \\
\hline 80,000 & 22 & 21 & \\
\hline 100,000 & 21 & 20 & Lock ring starting to separate. \\
\hline 120,000 & 20 & 19 & $\begin{array}{l}\text { Bottom failed } 90^{\circ} \text { counterclockwise from point to load } \\
\text { (Figure } 43 \text { ). }\end{array}$ \\
\hline 125,000 & $19-1 / 2$ & $18-1 / 2$ & Bottom failed $90^{\circ}$ clockwise from load point (Figure 44 ) \\
\hline
\end{tabular}

(C) 17C Container with 6 C-Clamps Over Lock Ring

$\begin{array}{rlll}0 & 24 & 23-7 / 8 & \\ 40,000 & 23 & 22-1 / 8 & \\ 60,000 & 22-1 / 2 & 22 & \text { Lock ring starting to separate. } \\ 80,000 & 22 & 21-3 / 8 & \text { Lid starting to crease across horizontal center line. } \\ 100,000 & 21 & 20-3 / 4 & \text { Lid creasing at load points. } \\ 105,000 & & & \text { Lid failed adjacent to lug on lock ring (Figure } 46 \text { ). }\end{array}$

(D) $17 \mathrm{C}$ Container with 6 -inch Internal Lid

$\begin{array}{rlll}0 & 24 & 23-5 / 8 & \\ 40,000 & 23 & 23-1 / 2 & \\ 80,000 & 22-1 / 8 & 21 & \\ 100,000 & 21-1 / 4 & 20 & \begin{array}{l}\text { Lock ring starting to separate. } \\ \text { Lid creasing at load points - crease across horizontal } \\ \text { center line }\end{array} \\ 110,000 & 21 & 19-5 / 8 & \begin{array}{l}\text { Bottom failed } 90^{\circ} \text { counterclockwise from load point } \\ \text { (Figure 47). } \\ \left.\text { Bottom failed } 90^{\circ} \text { clockwise from load point (Figure } 48\right) .\end{array}\end{array}$


TABLE II

Closure Techniques Rated by Categories

\begin{tabular}{|c|c|c|c|c|c|c|}
\hline & $\begin{array}{c}\text { Impact } \\
\text { Protection } \\
\end{array}$ & $\begin{array}{c}\text { Static } \\
\text { Protection } \\
\end{array}$ & $\begin{array}{c}\text { Added } \\
\text { Cost } \\
\end{array}$ & $\begin{array}{l}\text { Redesign } \\
\text { Required } \\
\end{array}$ & $\begin{array}{c}\text { Ease of } \\
\text { Assembly } \\
\end{array}$ & $\begin{array}{c}\text { Vulnerability } \\
\text { to Operator } \\
\text { Error }\end{array}$ \\
\hline 6" Lid Extension & 1 & 1 & 2 & No & 1 & 1 \\
\hline 6" Inner Lid & 2 & 1 & 3 & No & 2 & 1 \\
\hline $6 \mathrm{C}$-Clamp & 3 & 2 & 1 & No & 3 & 2 \\
\hline Harry Fine & 2 & $?$ & 2 & No & 3 & 2 \\
\hline
\end{tabular}

TABLE III

Estimated Costs of Closure Techniques

Unit Cost of Technique

\begin{tabular}{|c|c|c|}
\hline Technique & 100 Unit Order $(\$)$ & 1000 Unit Order $(\$)$ \\
\hline 6" Lid Extention & 45.00 & 33.75 \\
\hline $6 "$ Inner Lid & 60.00 & 45.00 \\
\hline 6 C-Clamps (over ring) & 15.00 & 15.00 \\
\hline $12 \mathrm{C}$-Clamps (no ring) & 9.00 & 9.00 \\
\hline \multicolumn{3}{|l|}{ Clips } \\
\hline 6 - underside & 45.00 & 33.75 \\
\hline 12 - both sides & 90.00 & 67.50 \\
\hline $2^{\prime \prime}$ Ring Extension & 45.00 & 33.75 \\
\hline Harry Fine (not verified) & 52.00 & 41.00 \\
\hline
\end{tabular}




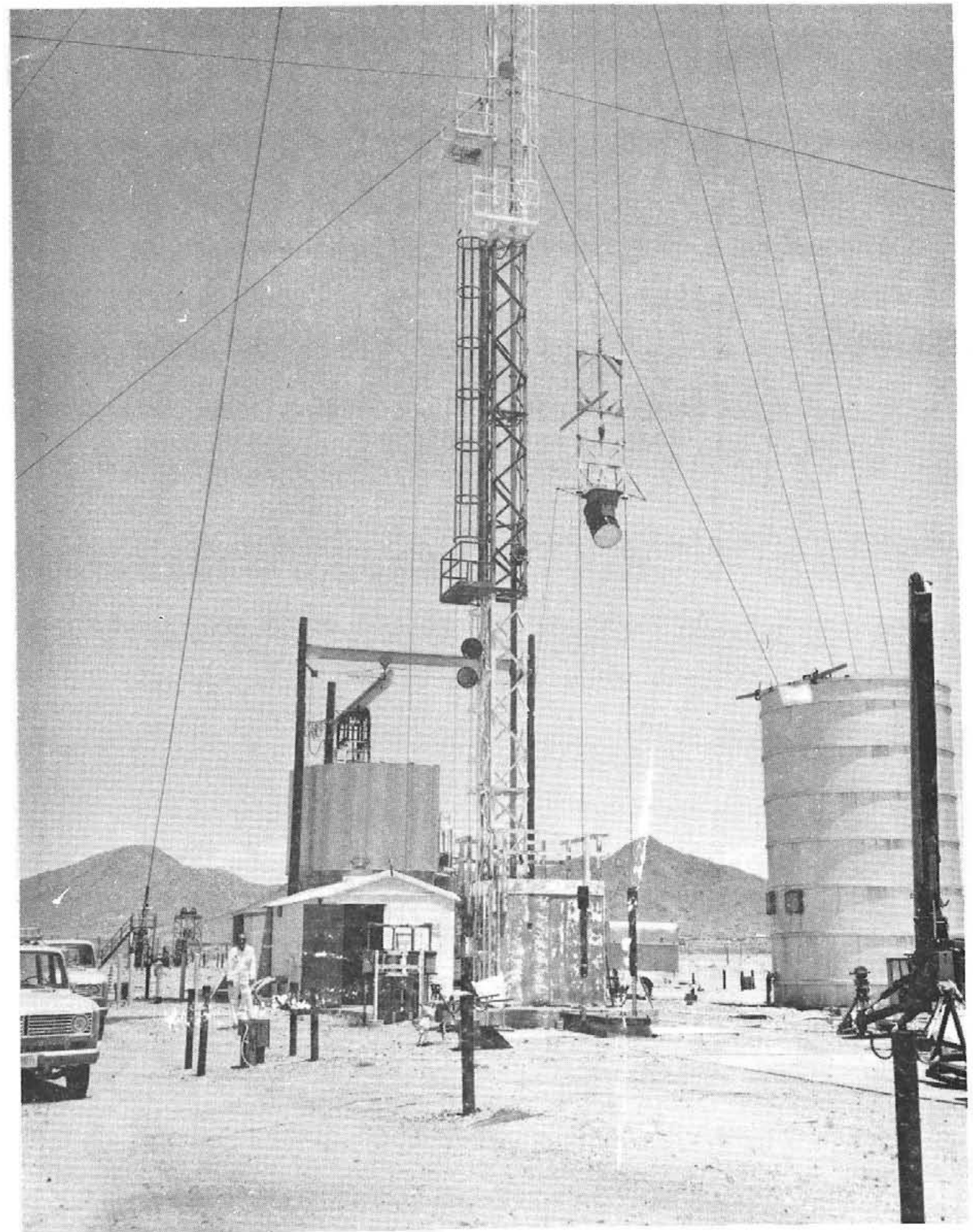

Figure 1. Sandia Laboratories ${ }^{t}$ Drop Tower Facility 


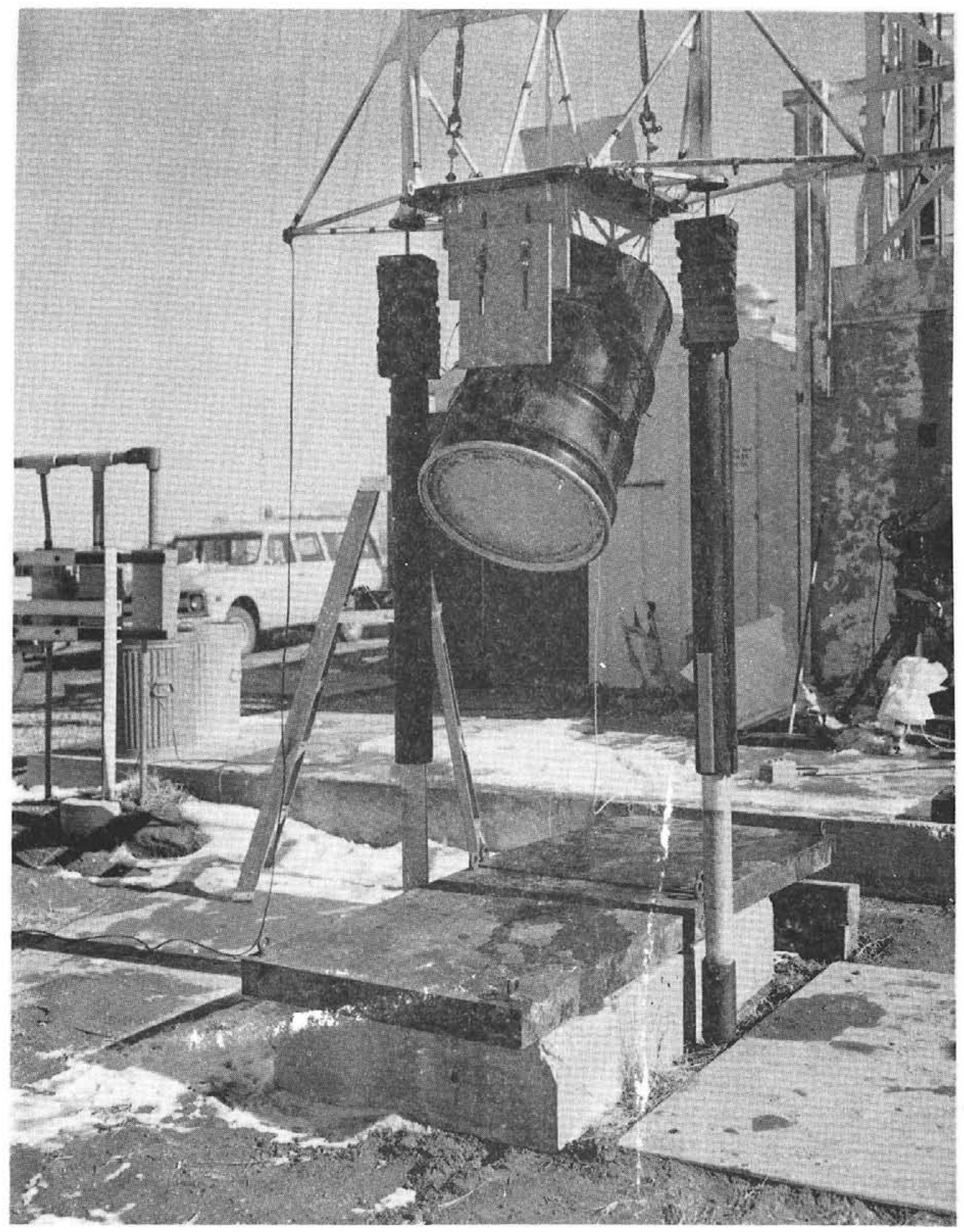

Figure 2. Test Fixture and Impact Surface 


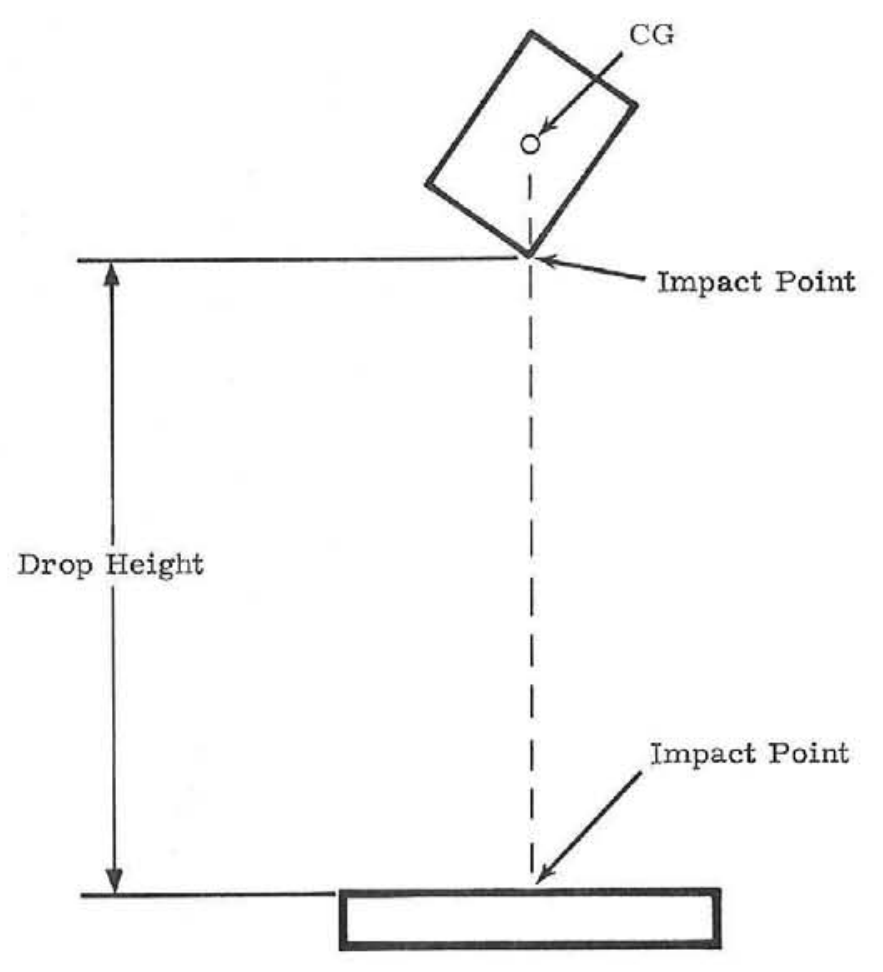

Figure 3. Drop Height and CG Location Relative to Impact

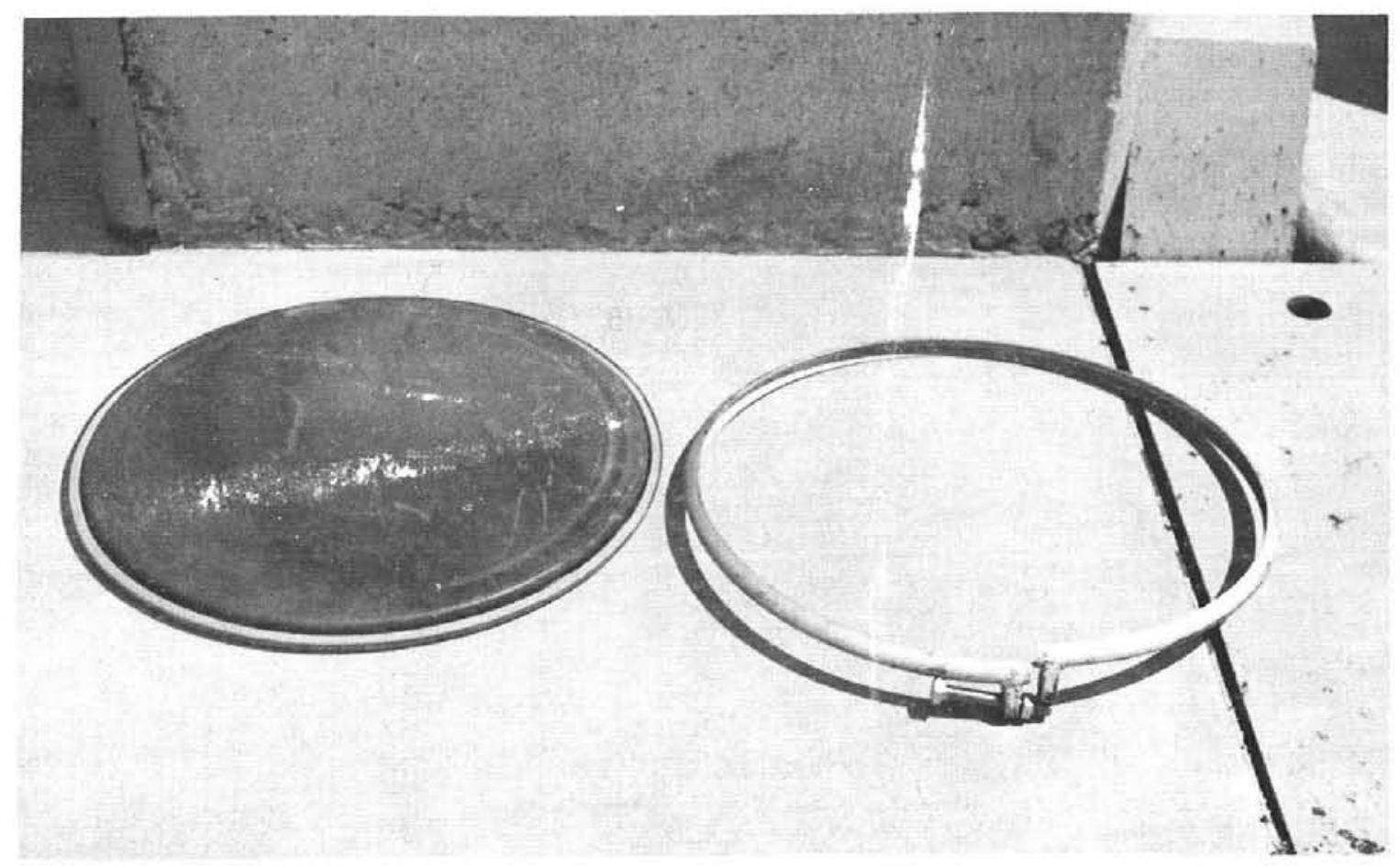

Figure 4a. Standard Lid and Lock Ring 


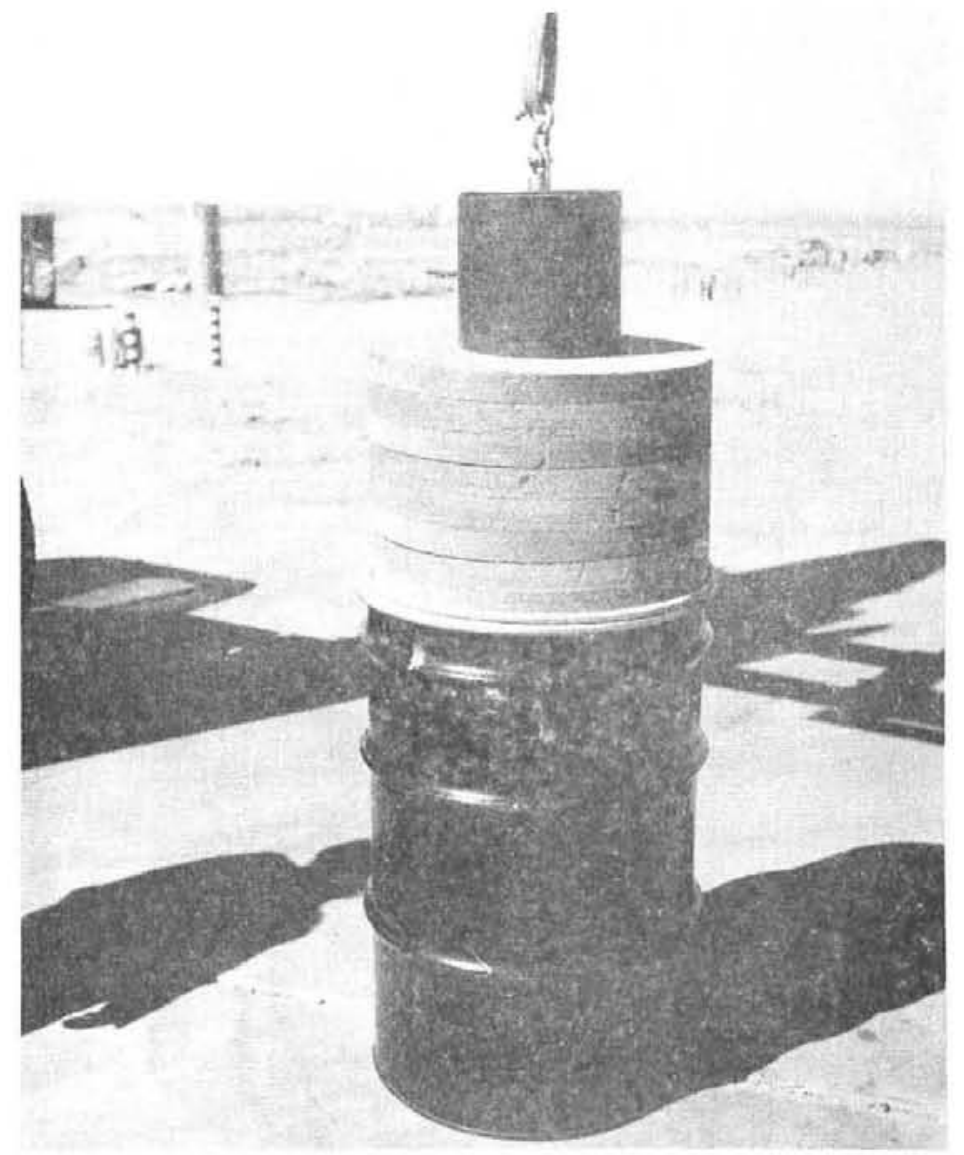

Figure 4b. 17C Container, Celotex Packing, and Inner Container

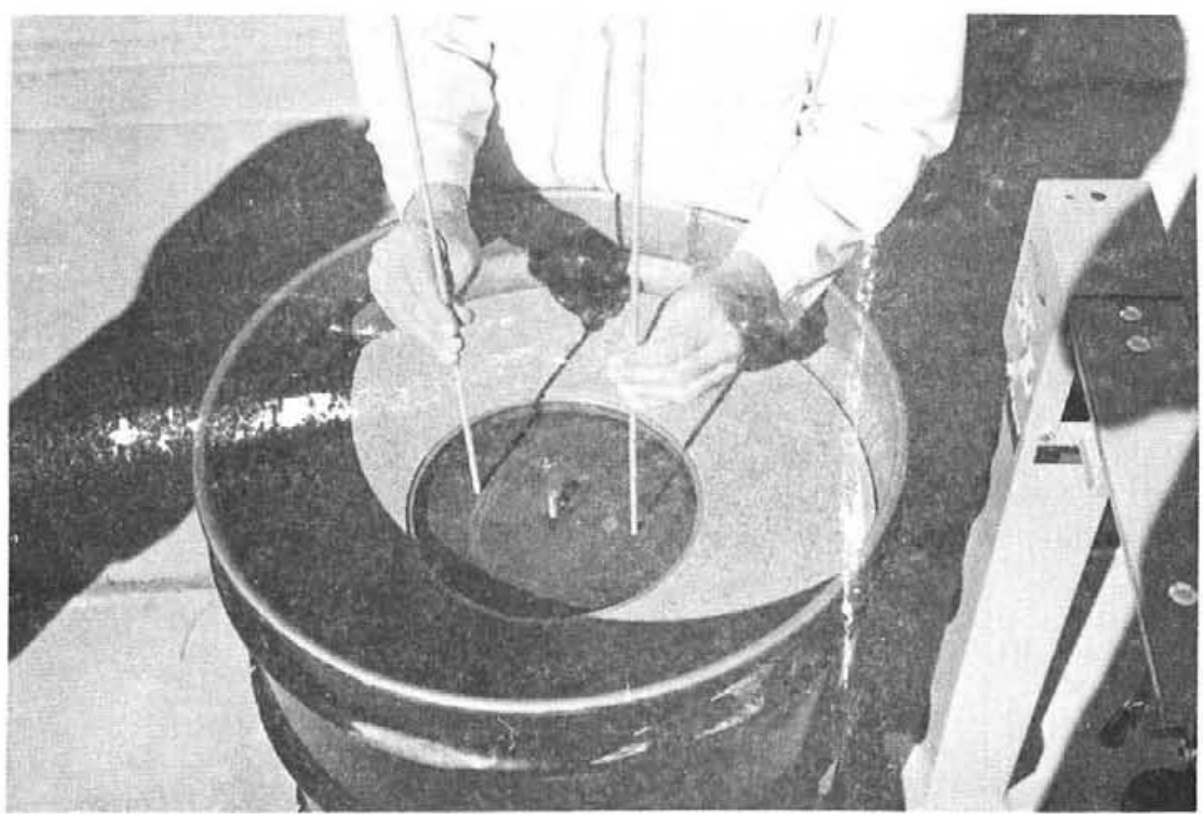

Figure 4c. Loading Lead Sheet Into Inner Container 


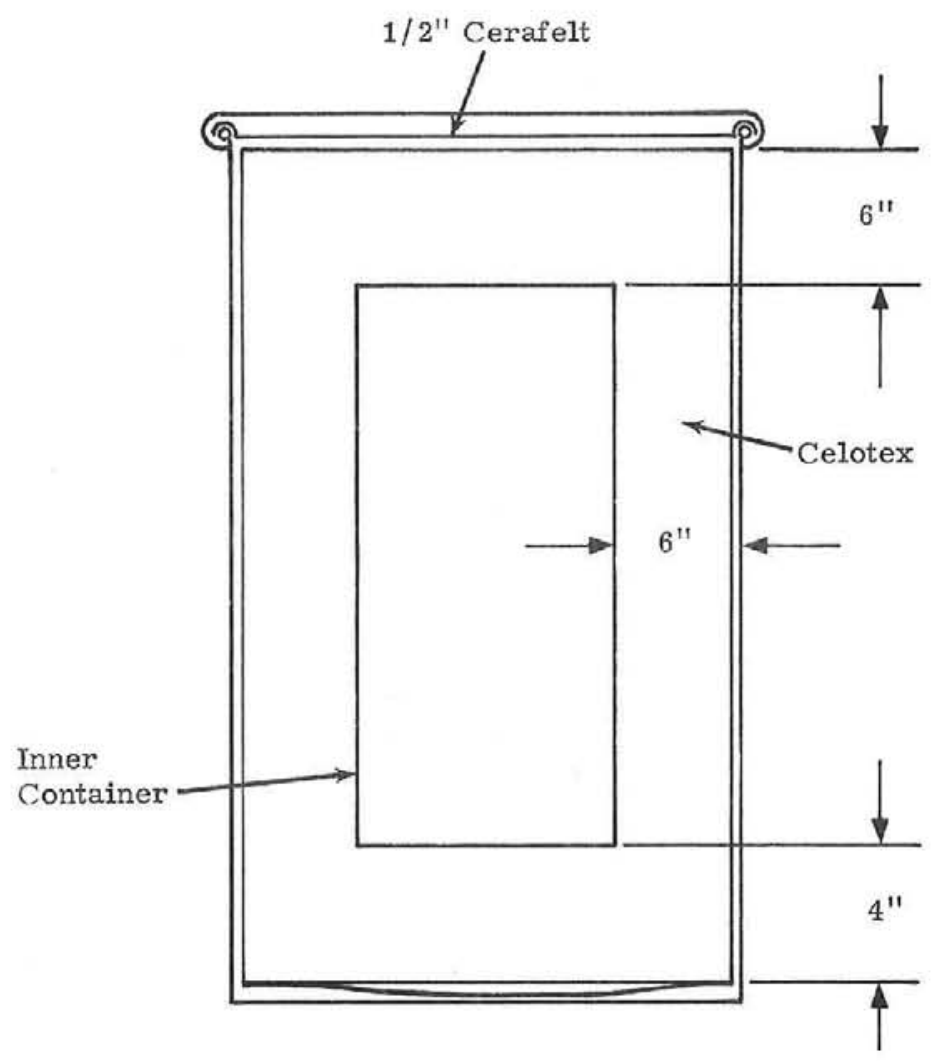

Figure 5. Packed Container

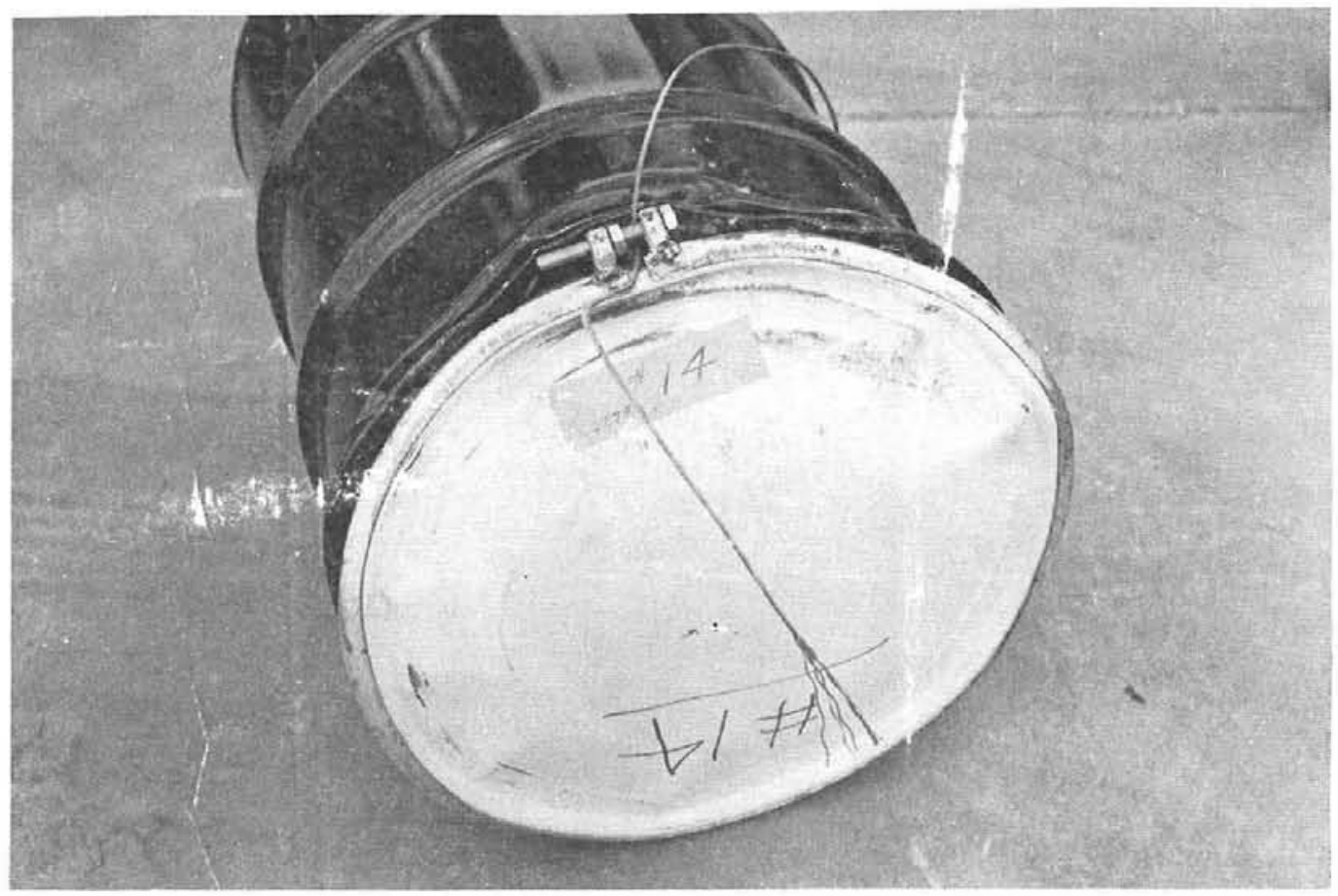

Figure 6. Standard 17C Drum - Success After 625-Pound, 30-Foot Drop 


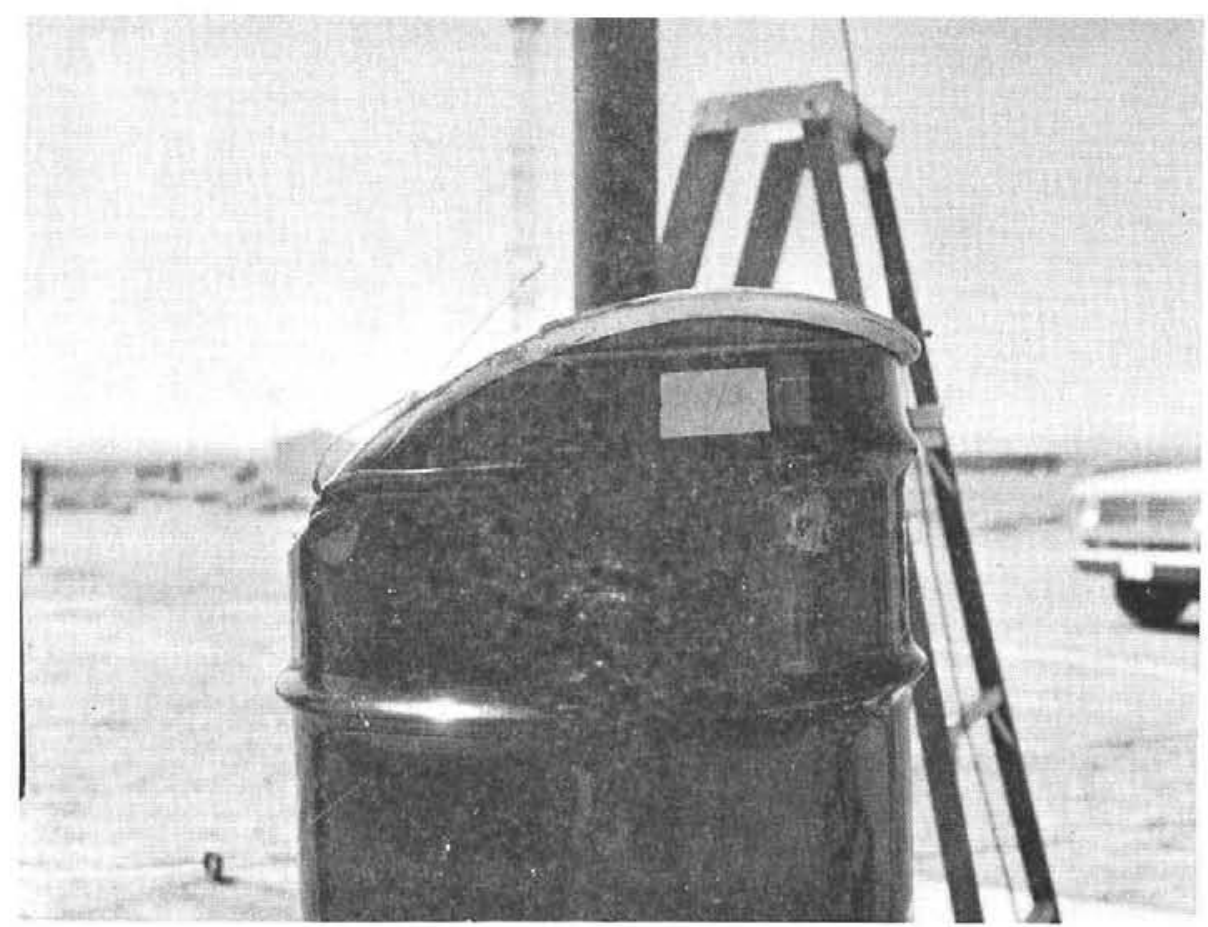

Figure 7. Standard 17C Drum - Failure After 650-Pound, 30-Foot Drop

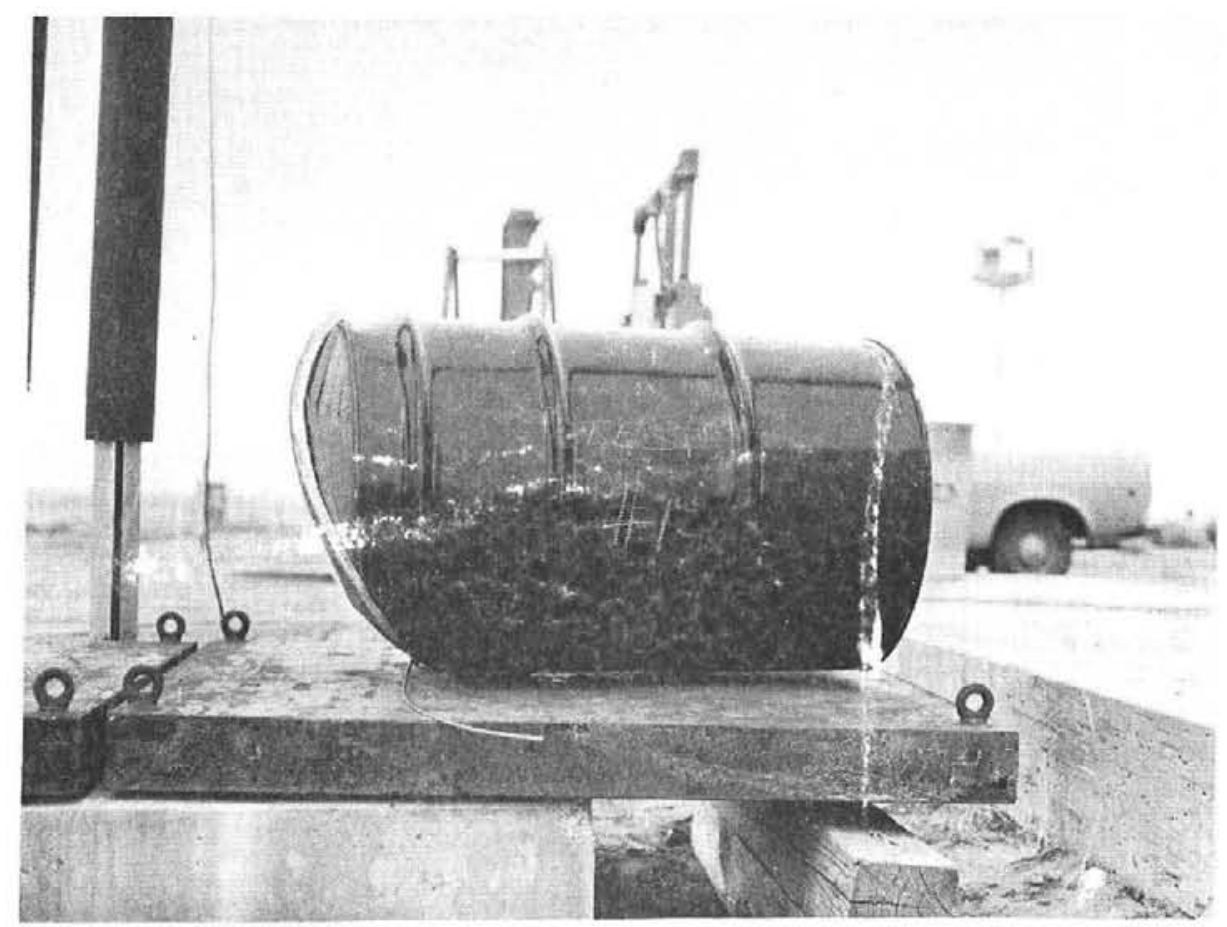

Figure 8. Standard 17C Drum - Failure After 1000-Pound, 30-Foot Drop 


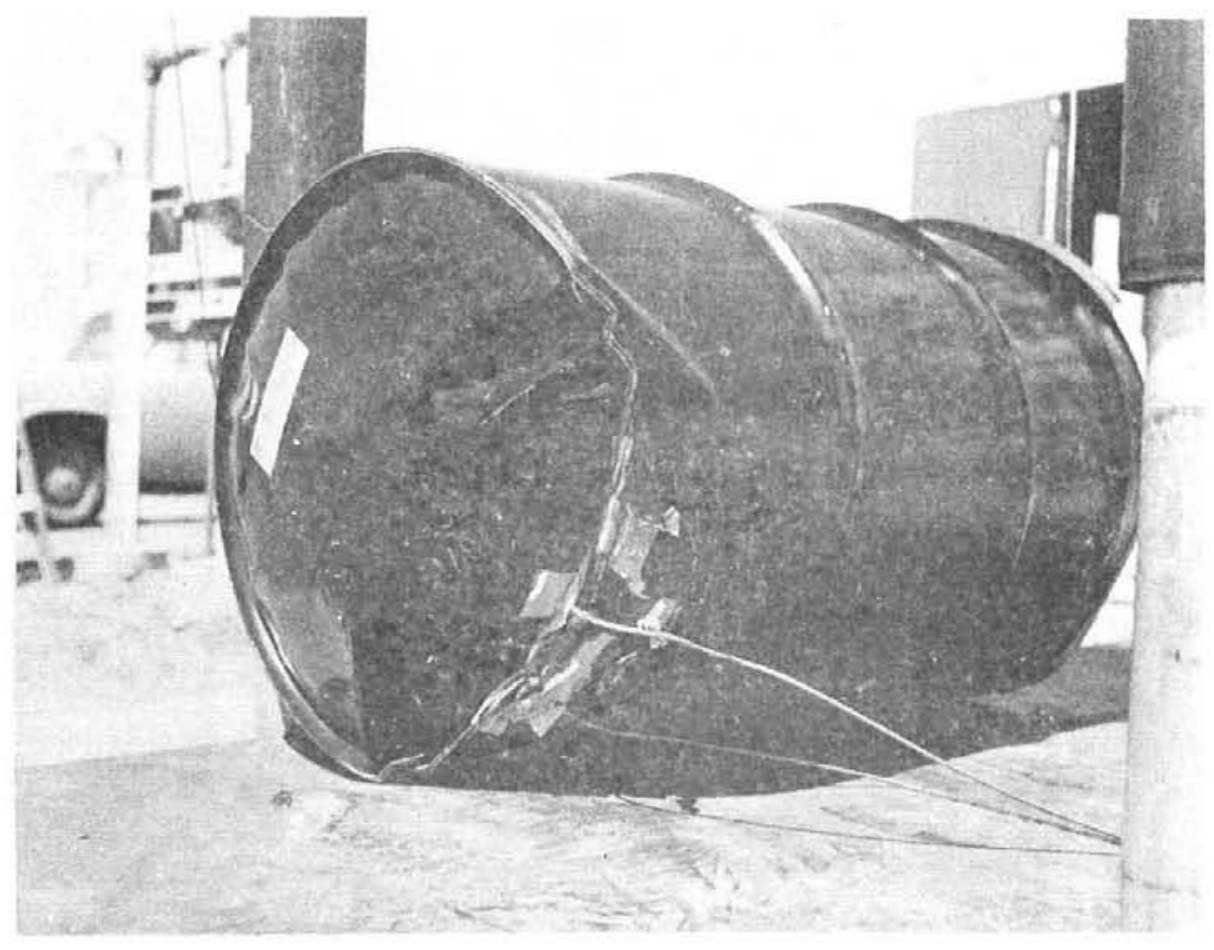

Figure 9. Standard 17C Drum - Bottom Impact on Seam, 1000 Pounds at 30 Feet

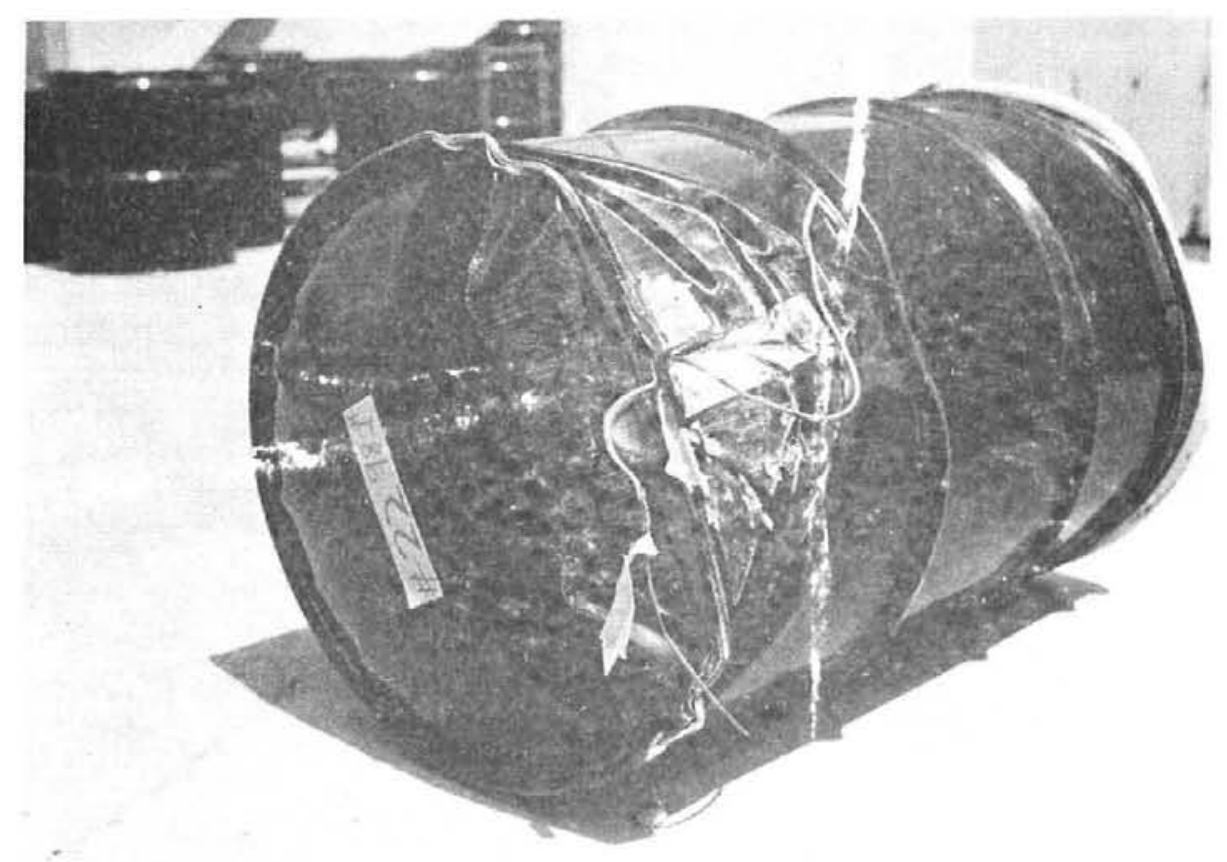

Figure 10. Standard 17C Drum - Bottom Impact $90^{\circ}$ from Seam, 1000 Pounds at 30 Feet 


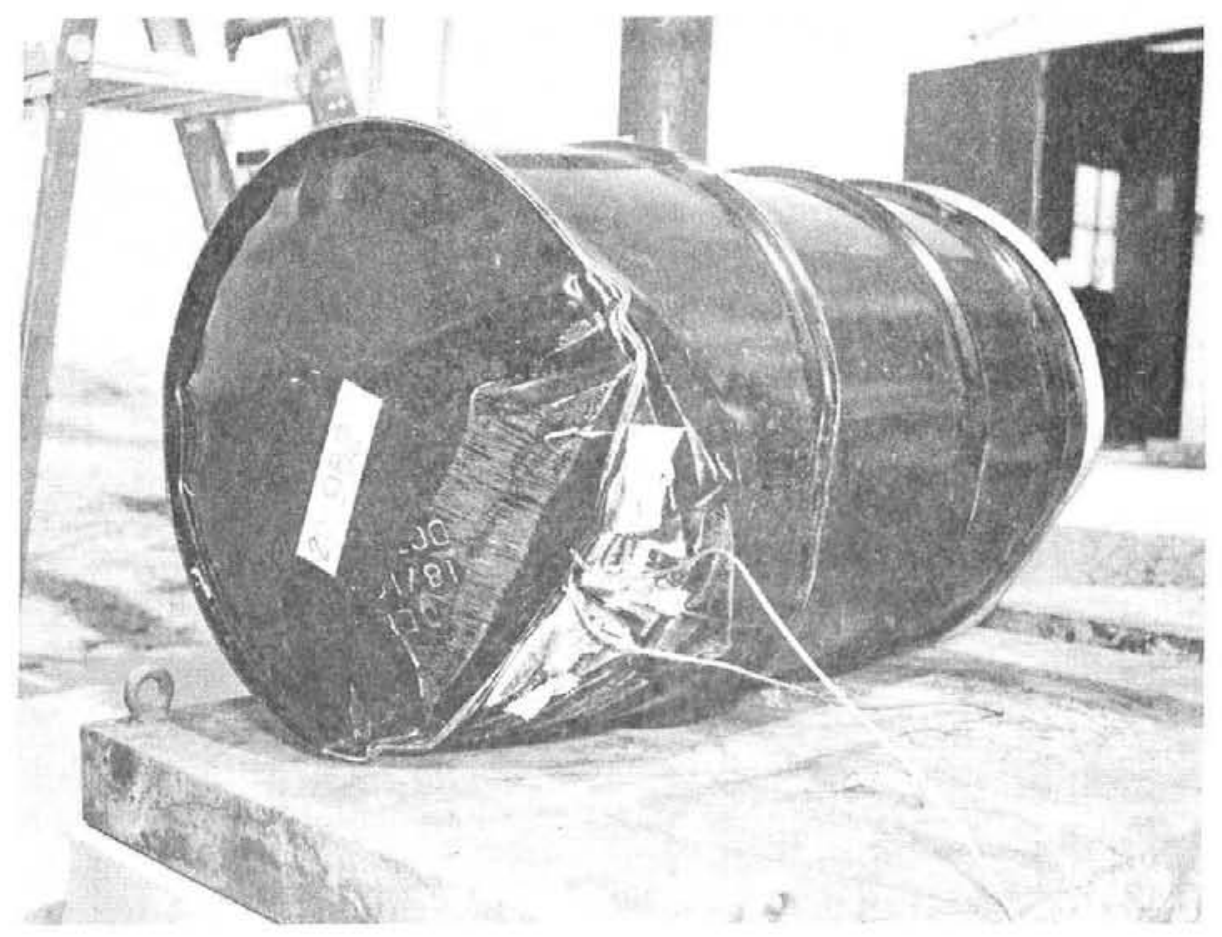

Figure 11. Standard 17C Drum - Bottom Impact, Seam on Crush Line, 1000 Pounds at 30 Feet

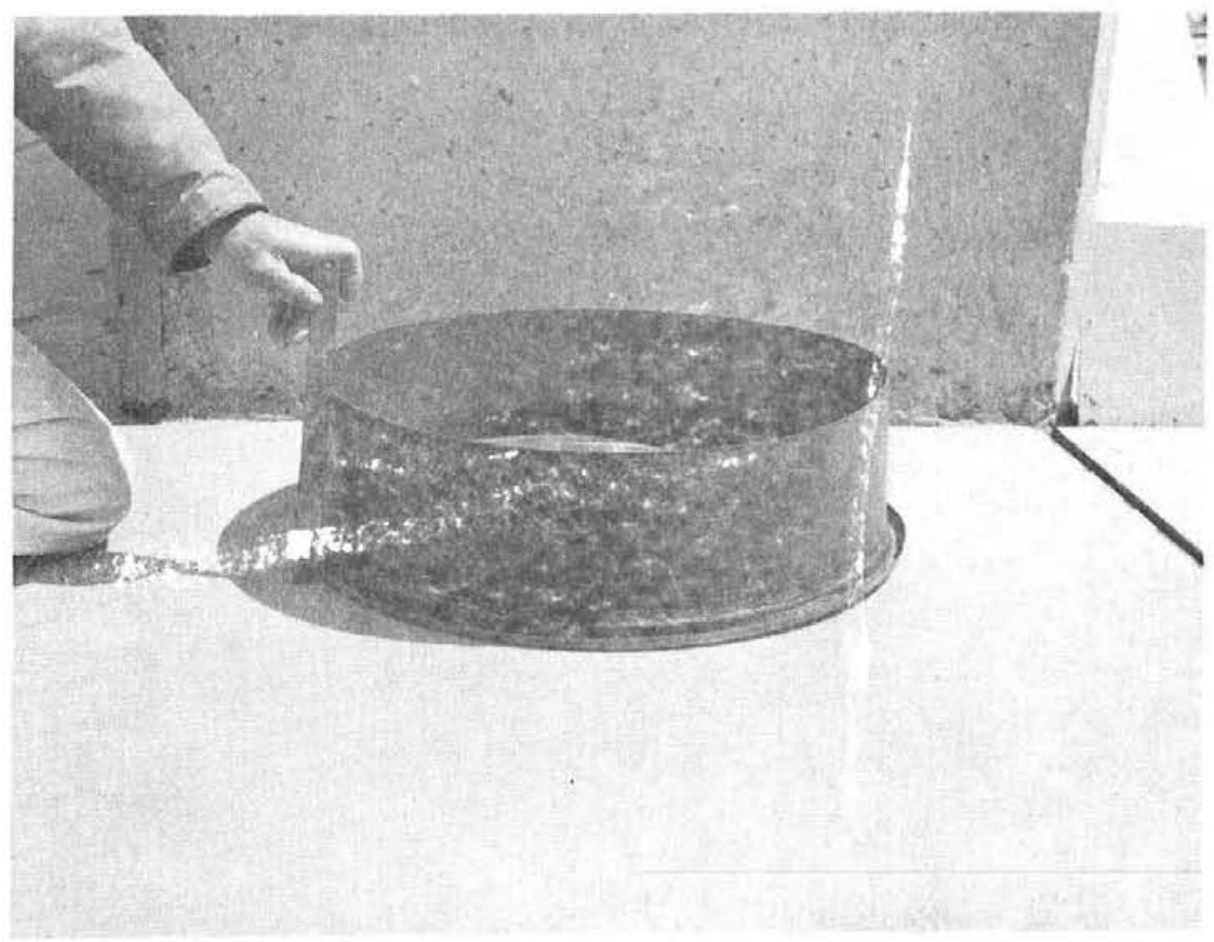

Figure 12. Standard Lid with 6-Inch Extension 


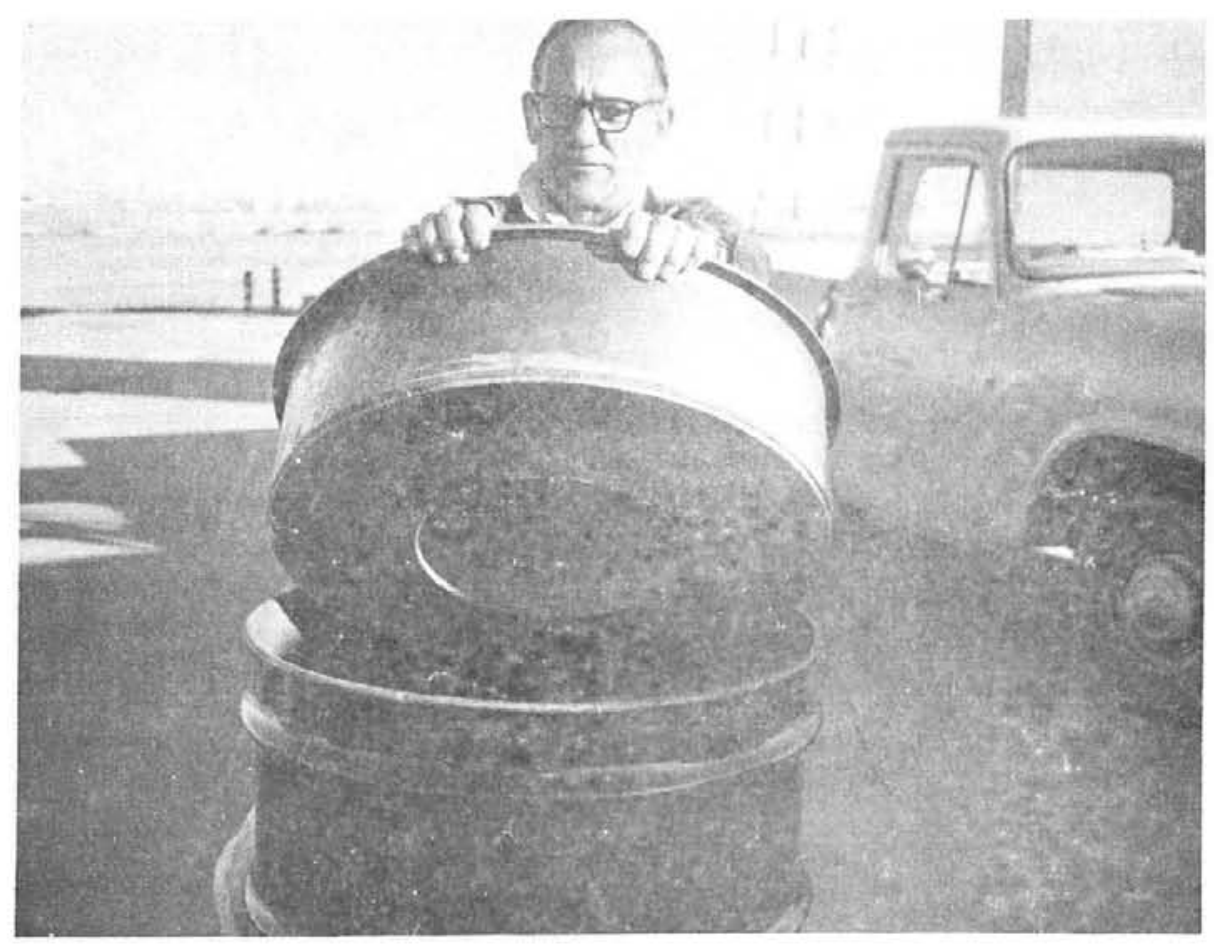

Figure 13. Celotex Packing Inside Lid Extension

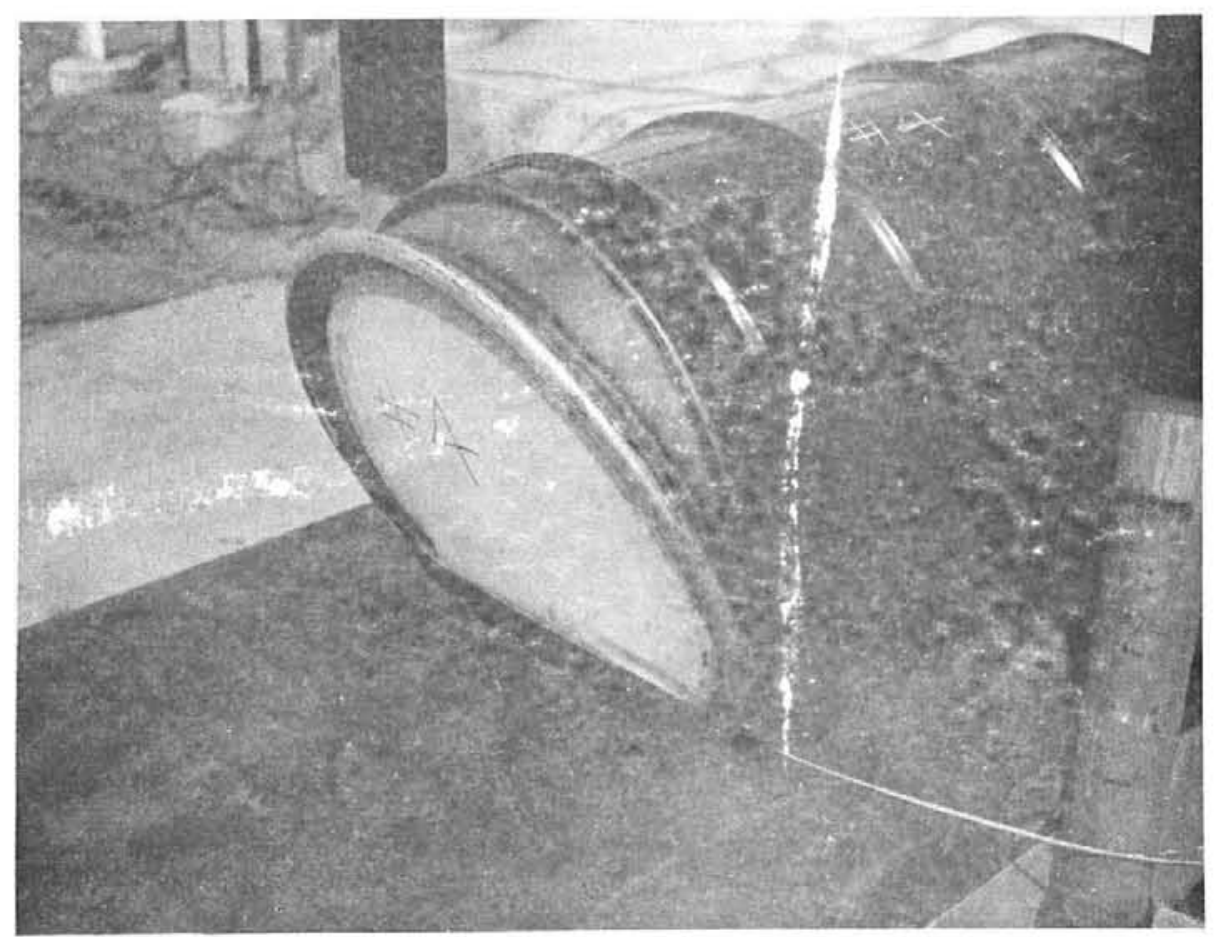

Figure 14. 6-Inch Lid Extension Technique - 1000 Pounds at 30 Feet 


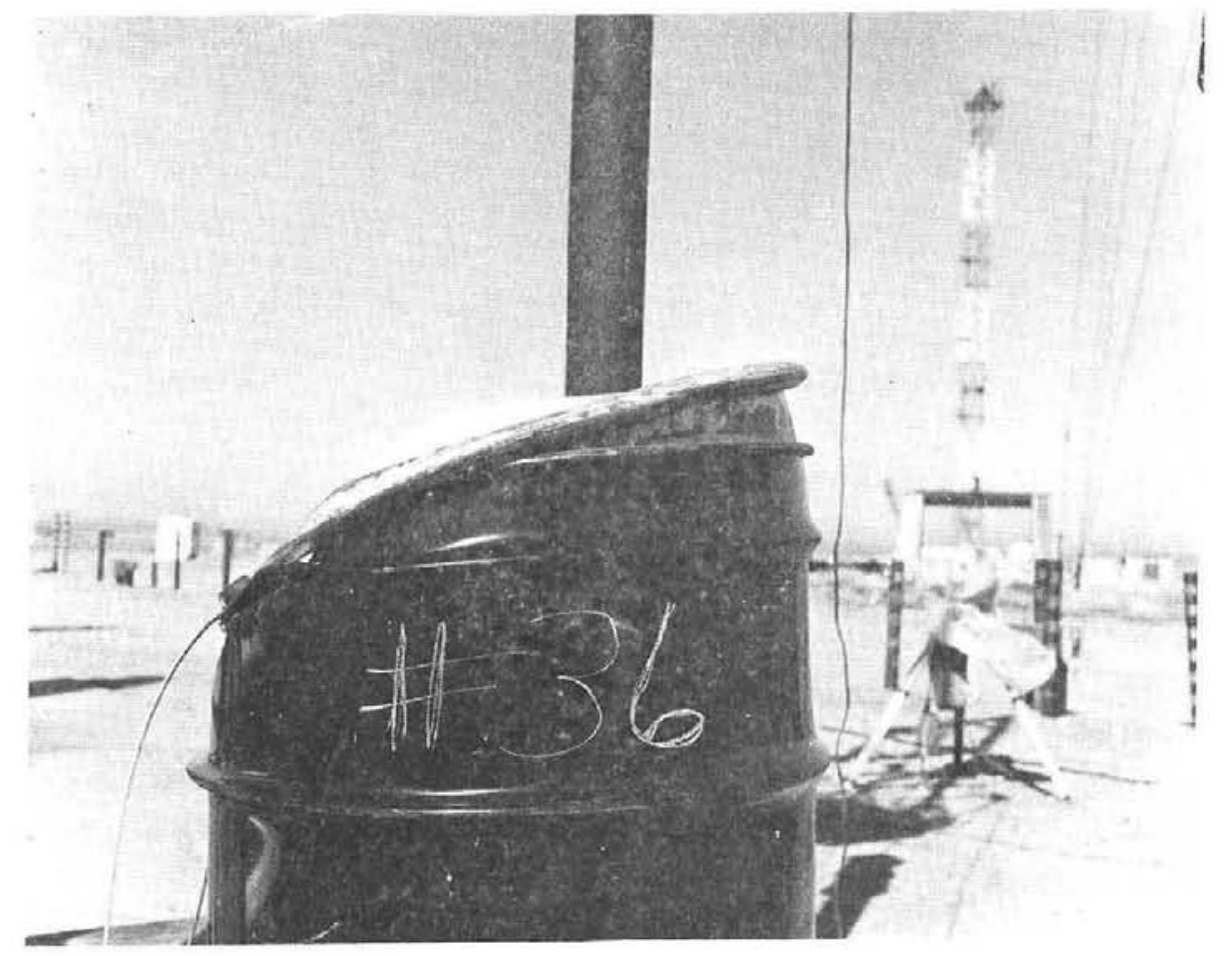

Figure 15. 6-Inch Lid Extension Technique - 1000 Pounds at 45 Feet

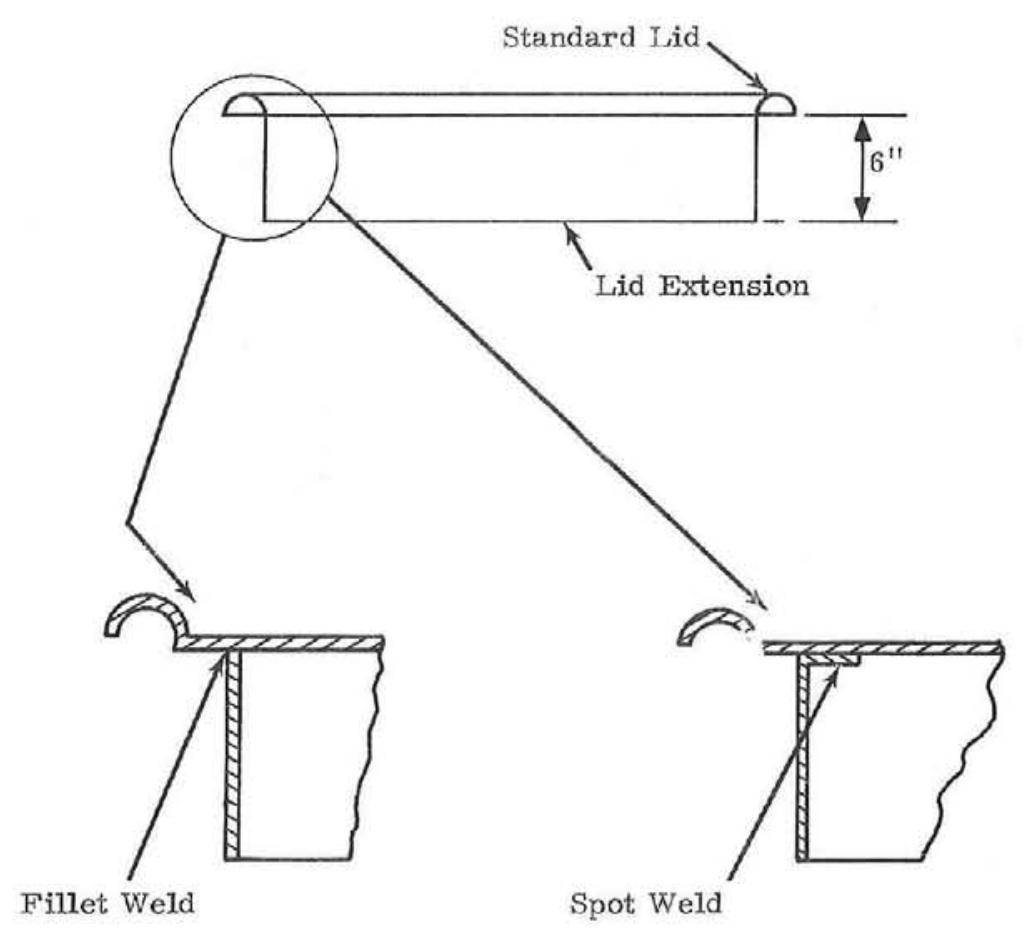

Figure 16. Attachment of 6-Inch Extension to Standard Lid 


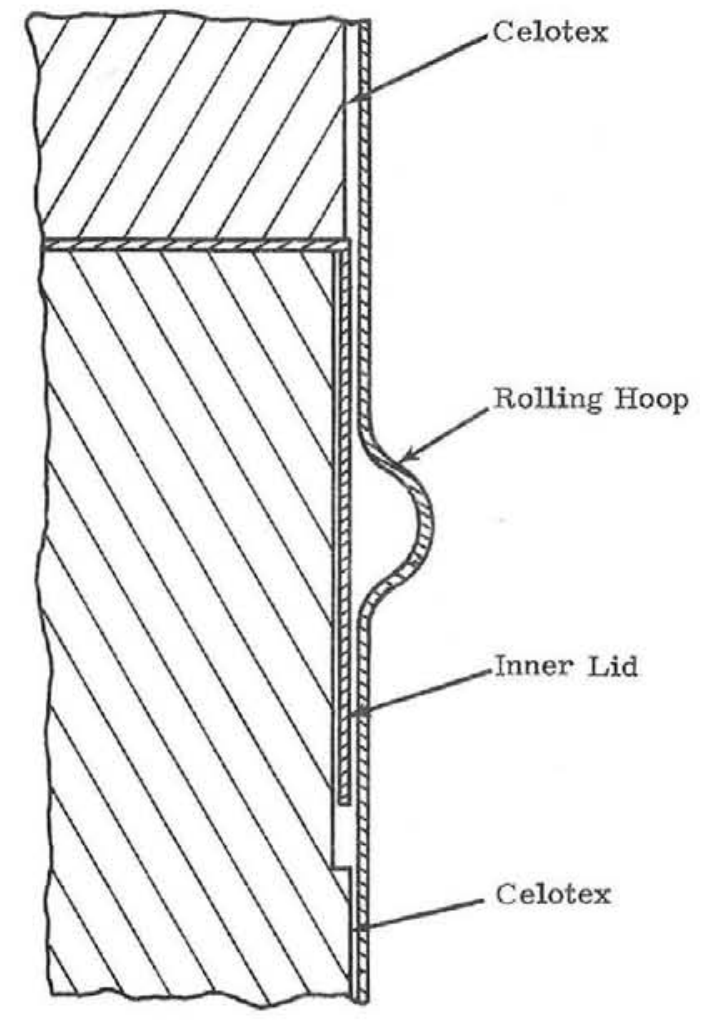

Figure 17. Inner Lid Details

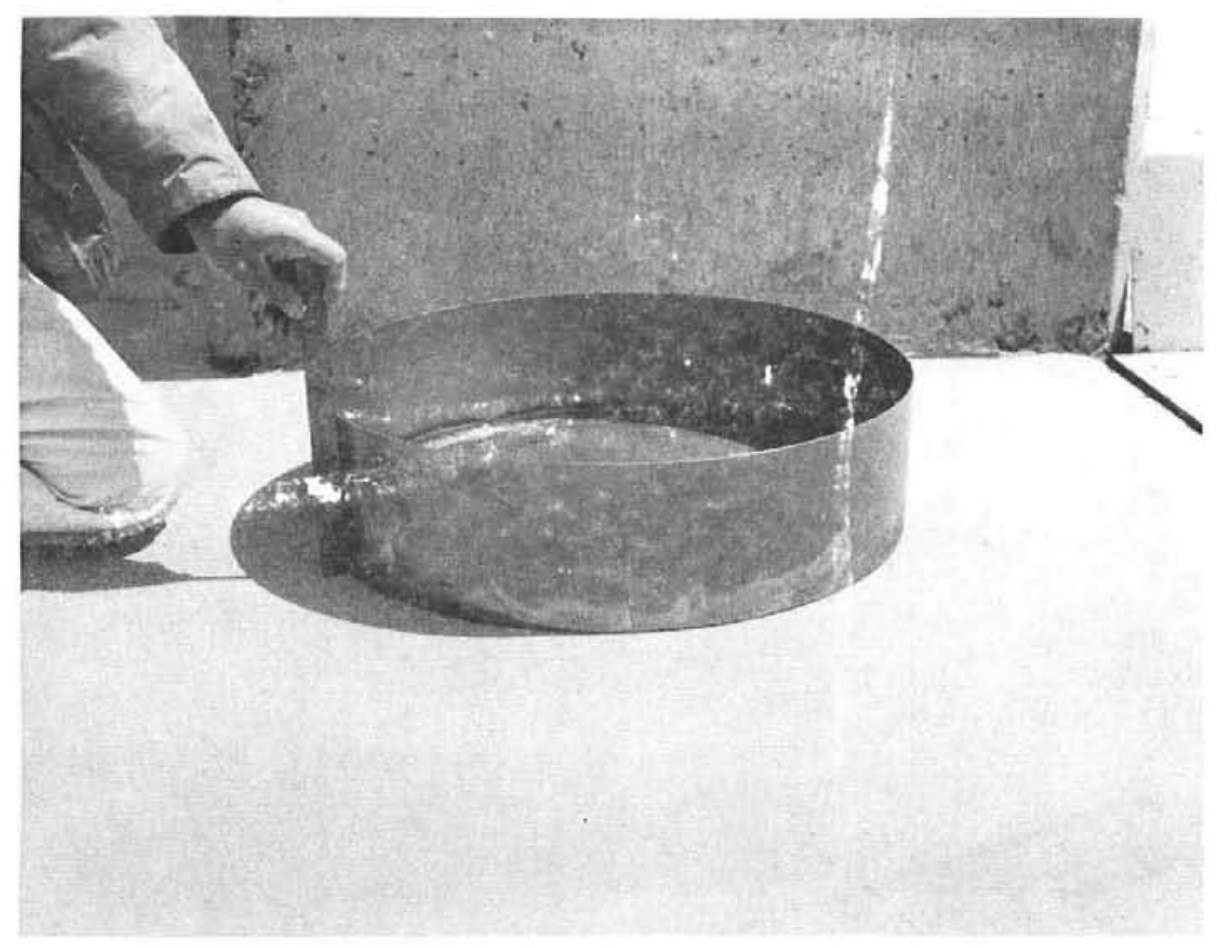

Figure 18. Inner Lid with 6-Inch Skirt 


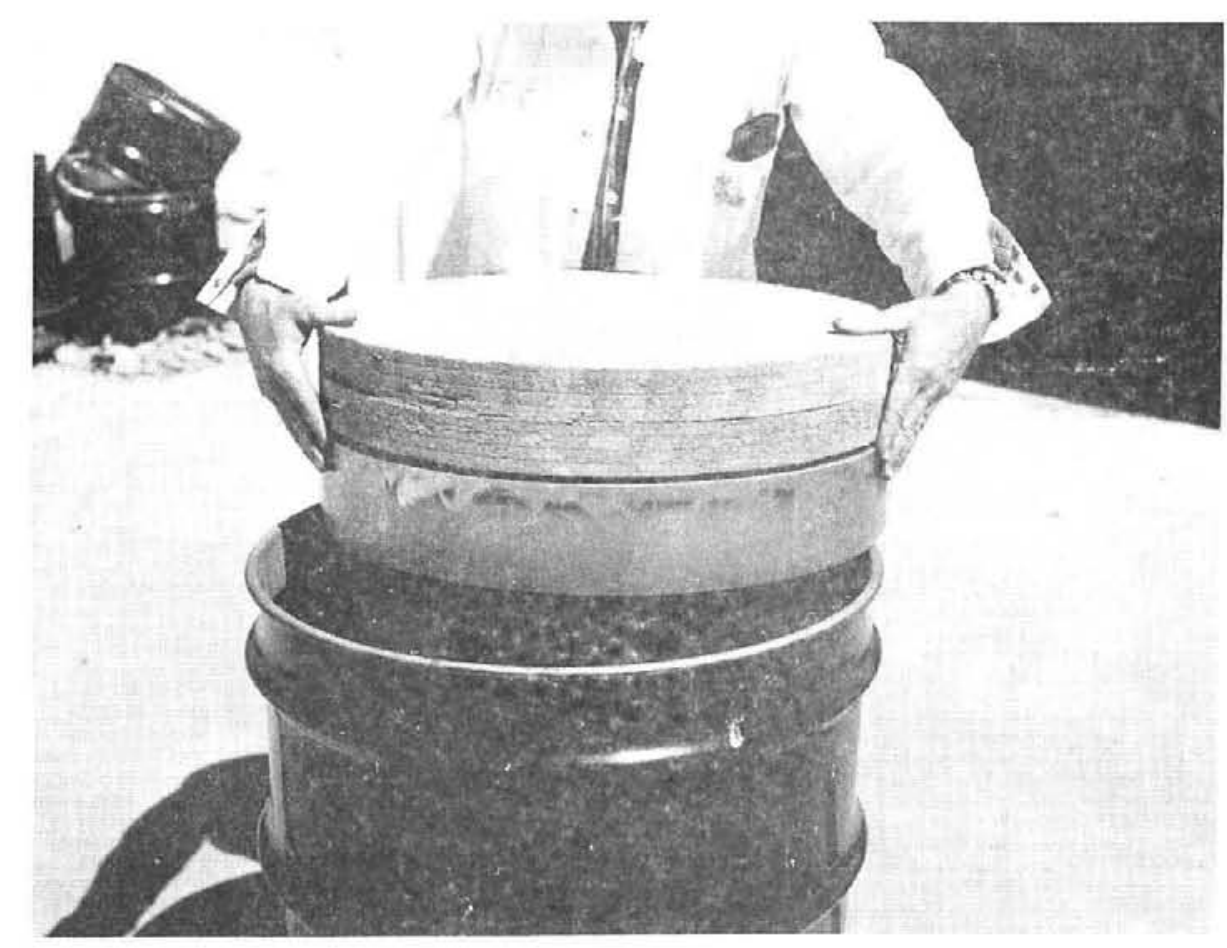

Figure 19. Packing of Inner Lid with 6-Inch Skirt

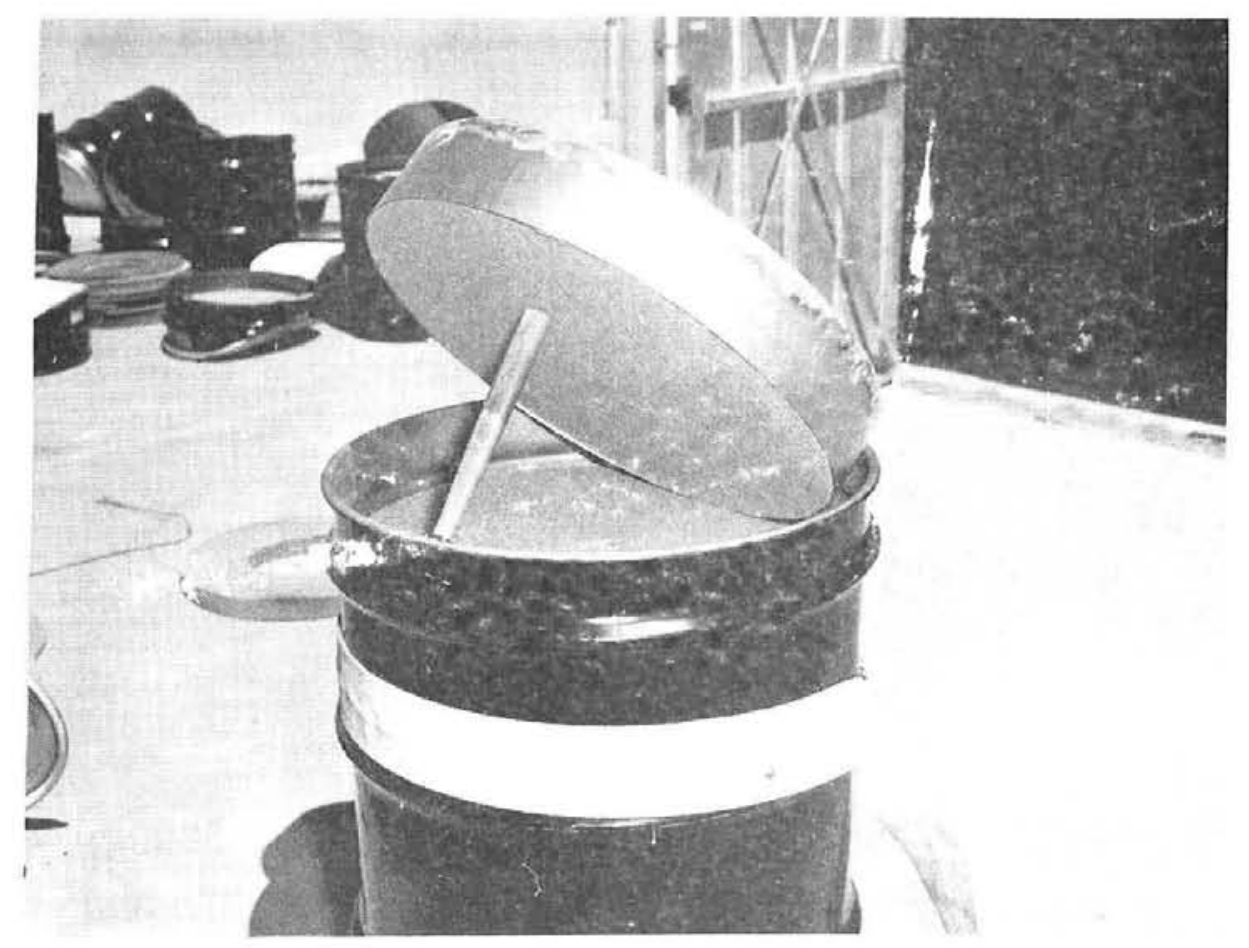

Figure 20. Installation of Inner Lid with 6-Inch Skirt 


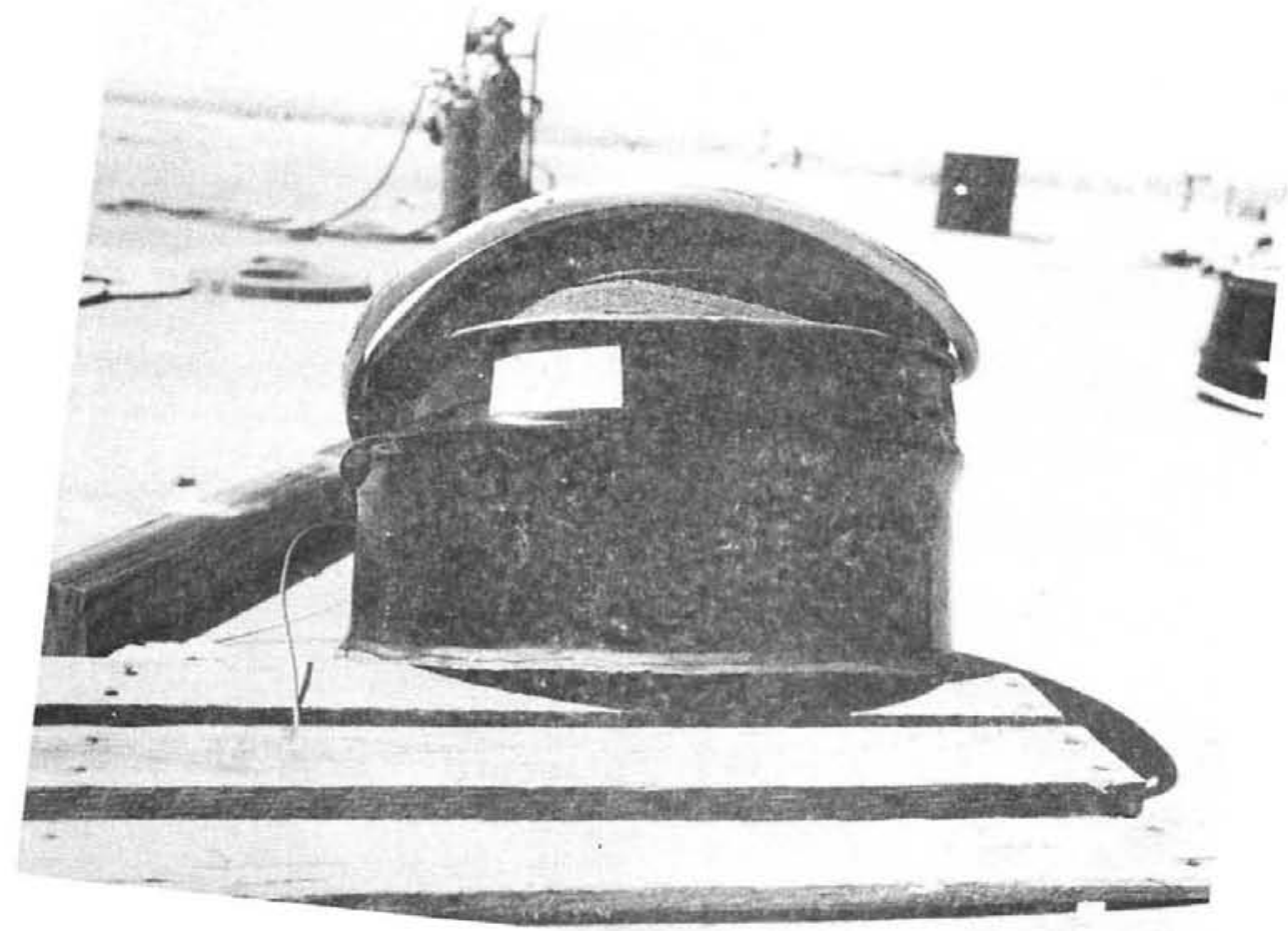

Figure 21. Inner Lid Technique- 1000 Pounds at

gure 21. Inner Lid Technique - 1000 Pounds at 30 Feet

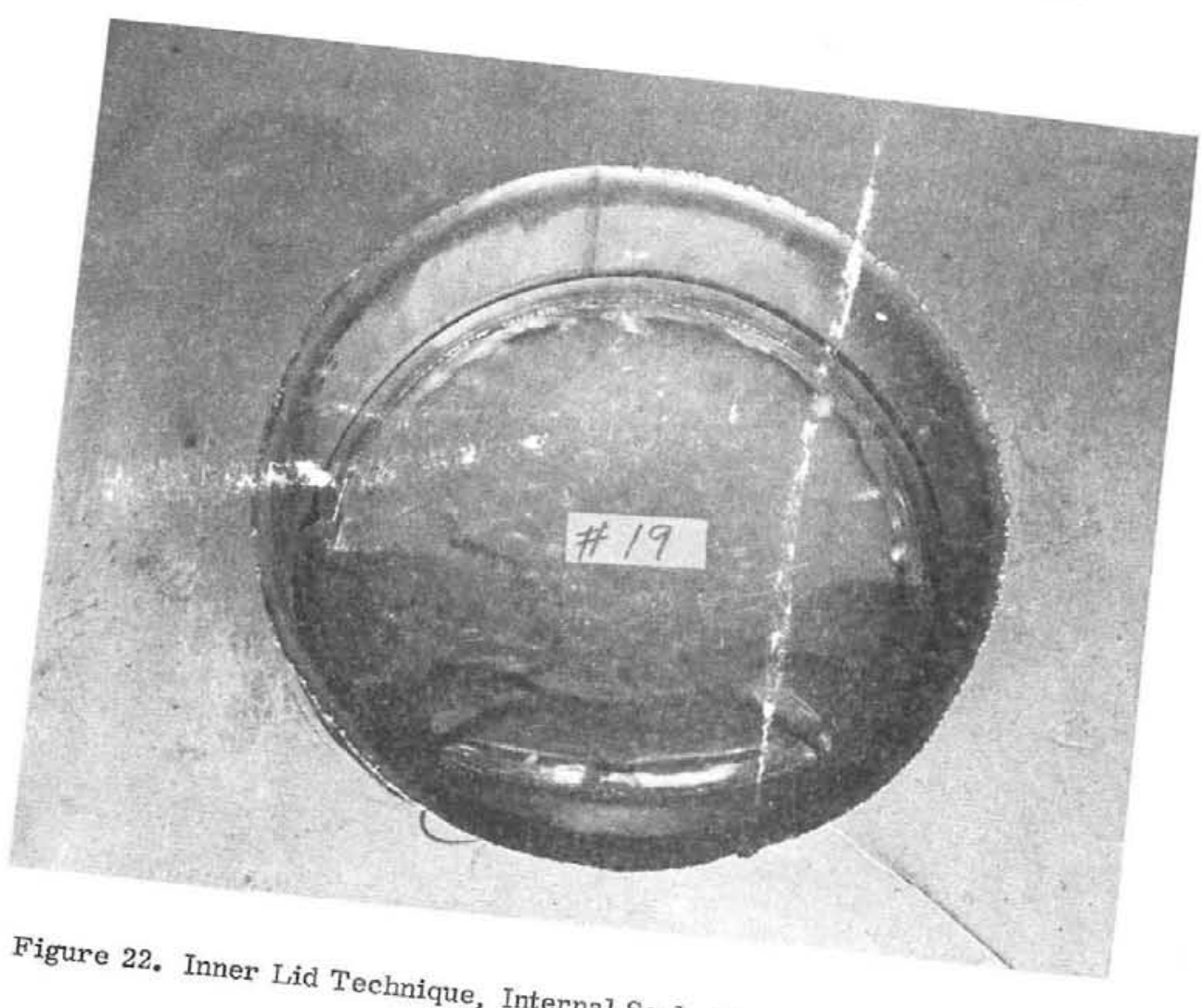




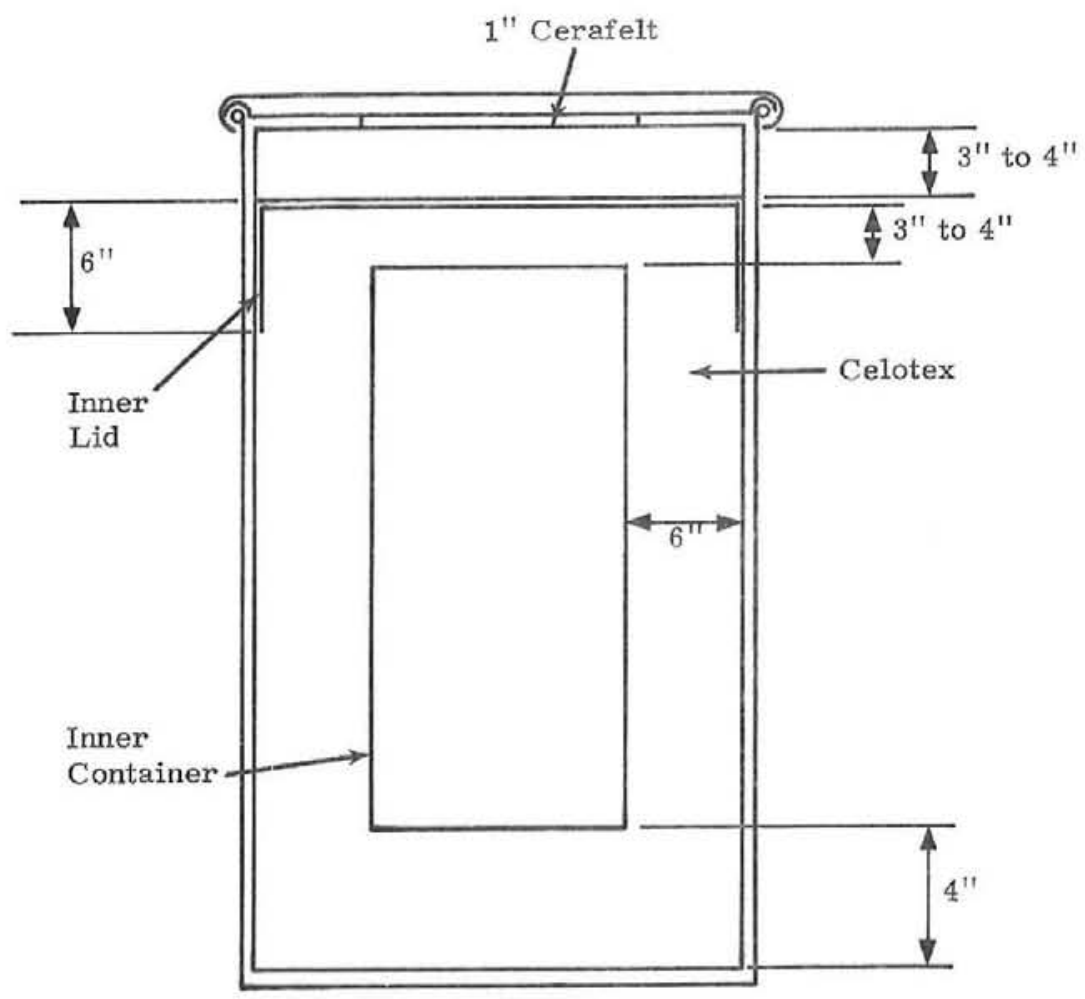

Figure 23. Packing with 6-Inch Internal Lid

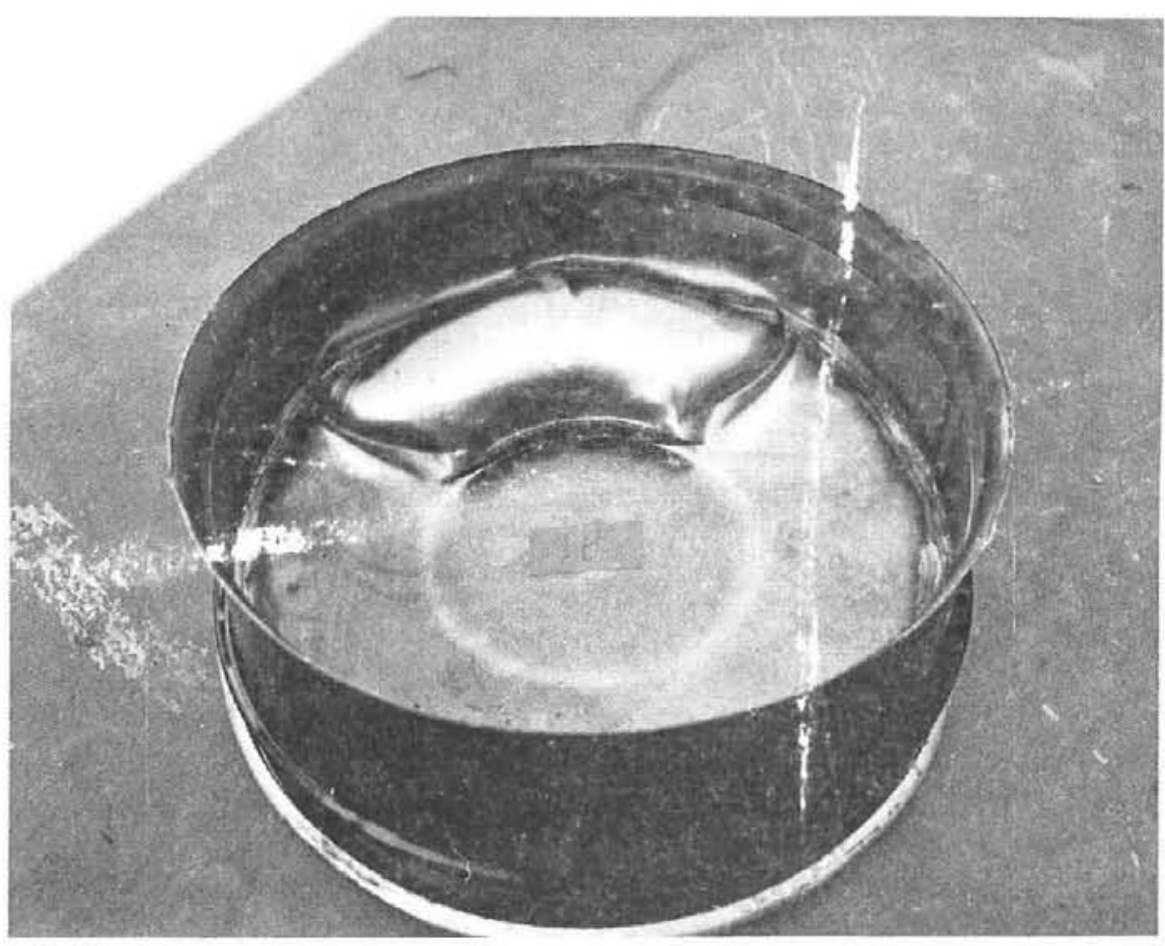

Figure 24. Shear of 6-Inch Internal Lid When Improperly Packed 


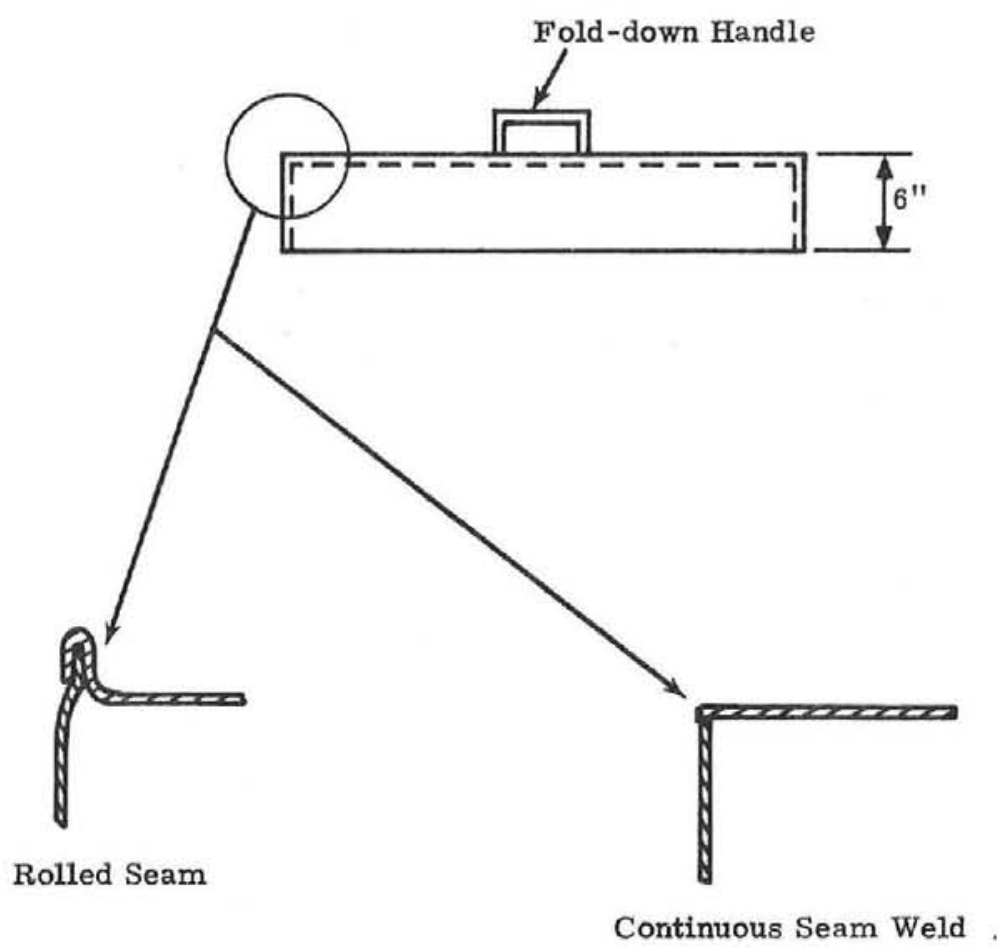

Figure 25. Details of 6-Inch Internal Lid

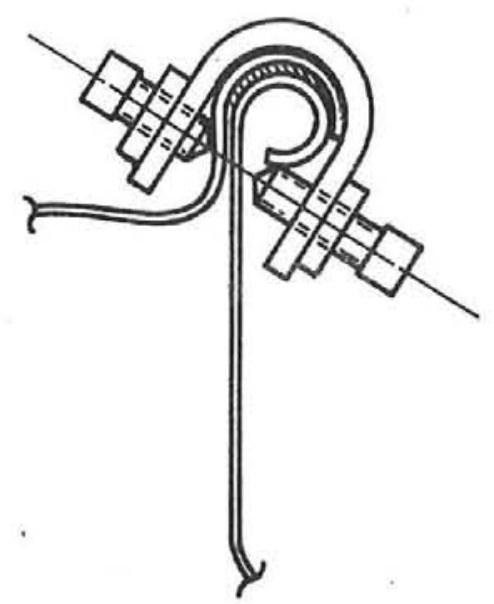

Figure 26. C-Clamp Without Lock Ring

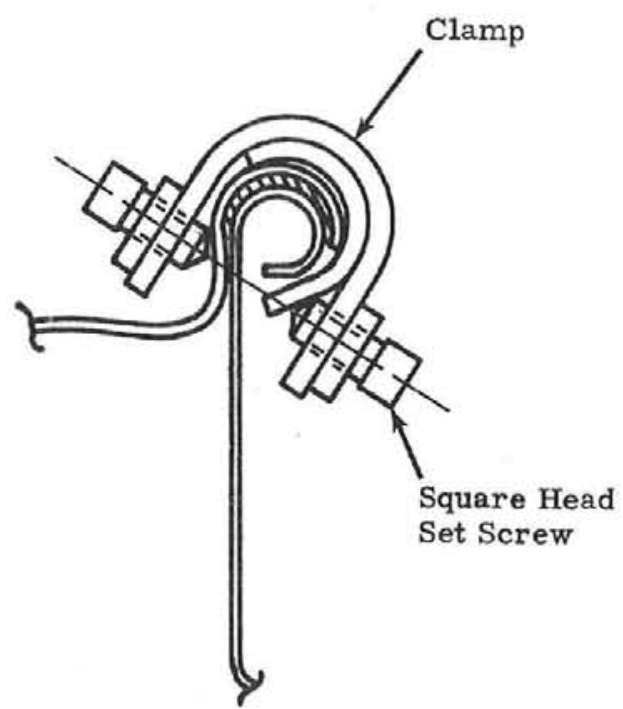

Figure 27. C-Clamp With'Lock Ring 


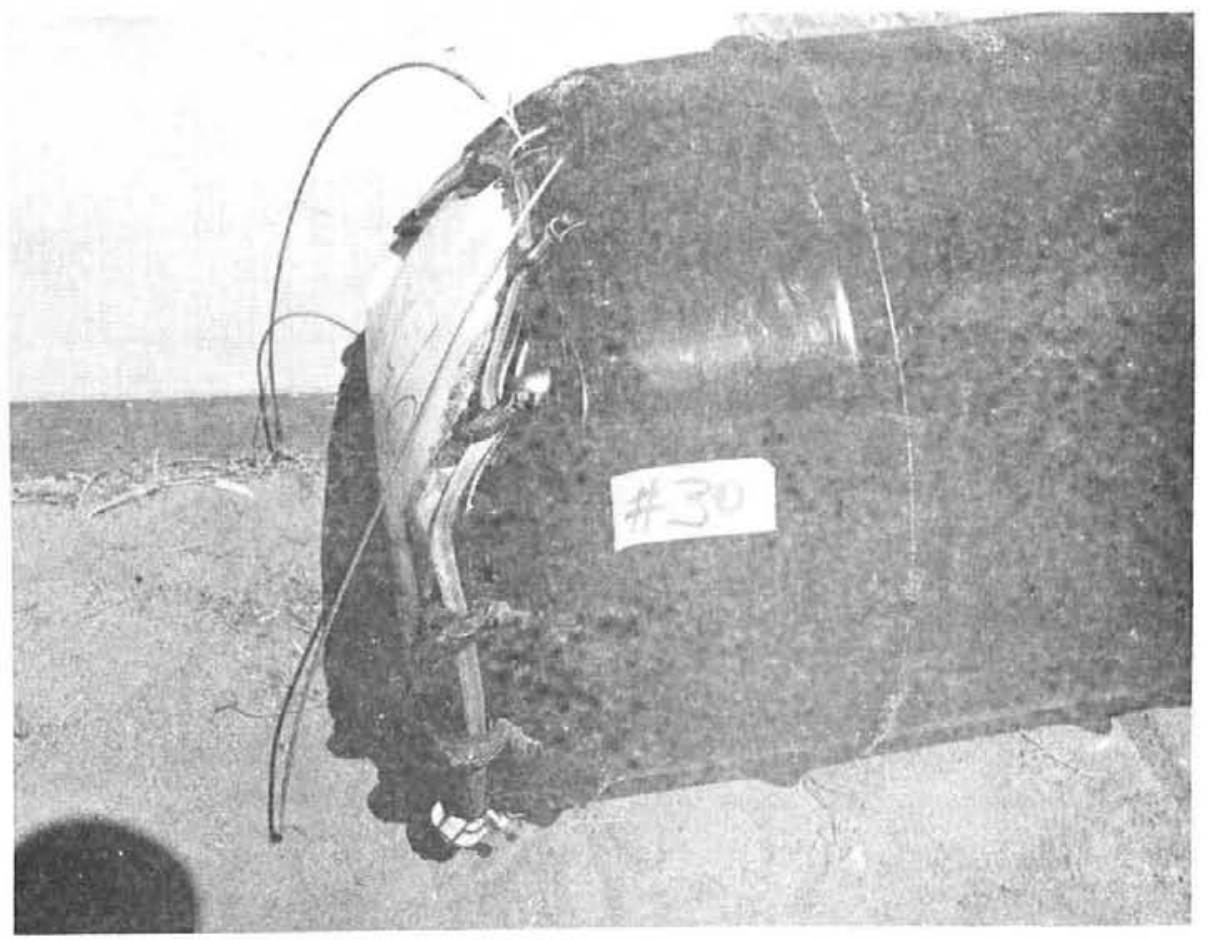

Figure 28. Posttest on 12 C-Clamps and No Lock Ring - 950 Pounds at 30 Feet

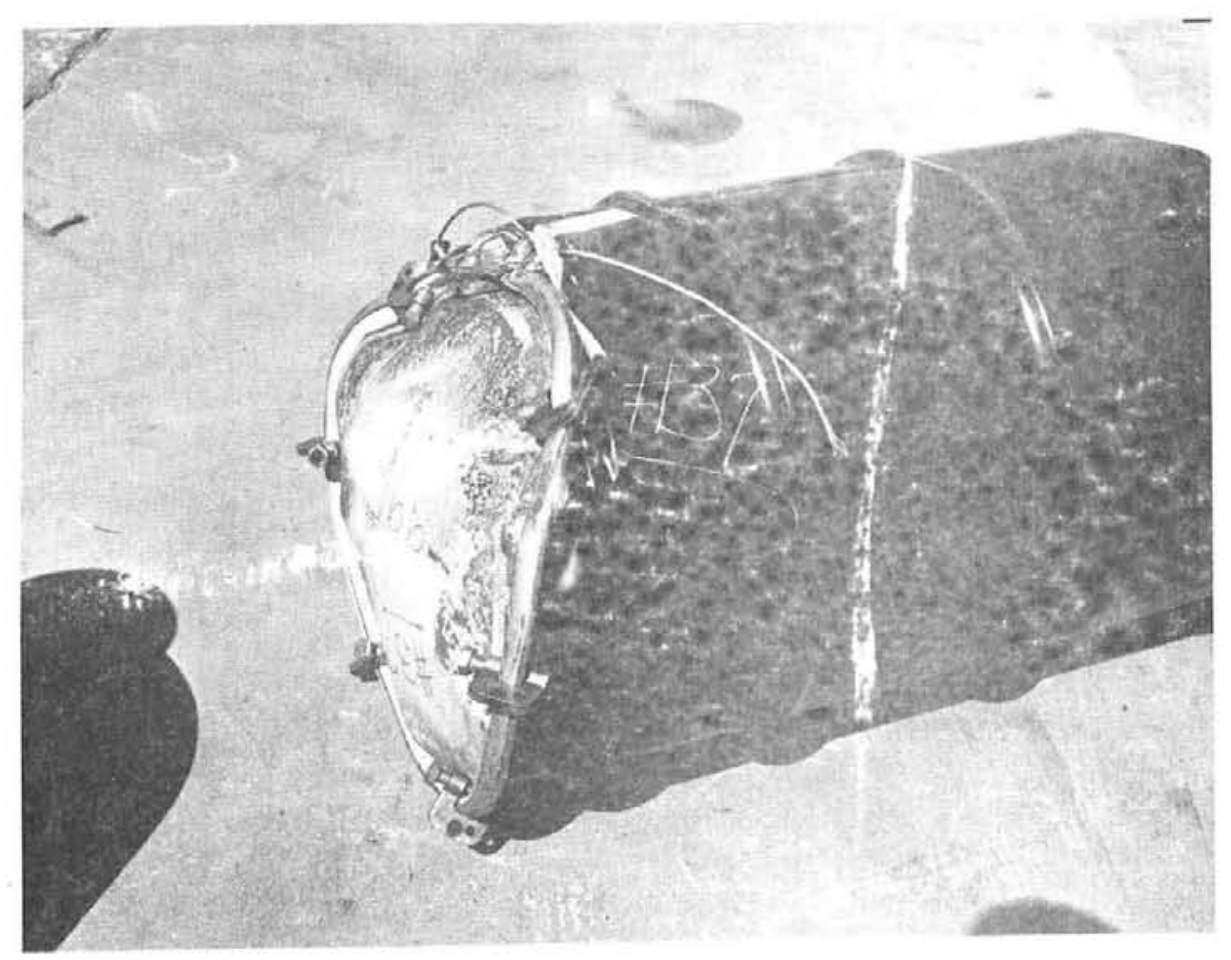

Figure 29. Posttest on 6 C-Clamps with Lock Ring - 1000 Pounds at 30 Feet 


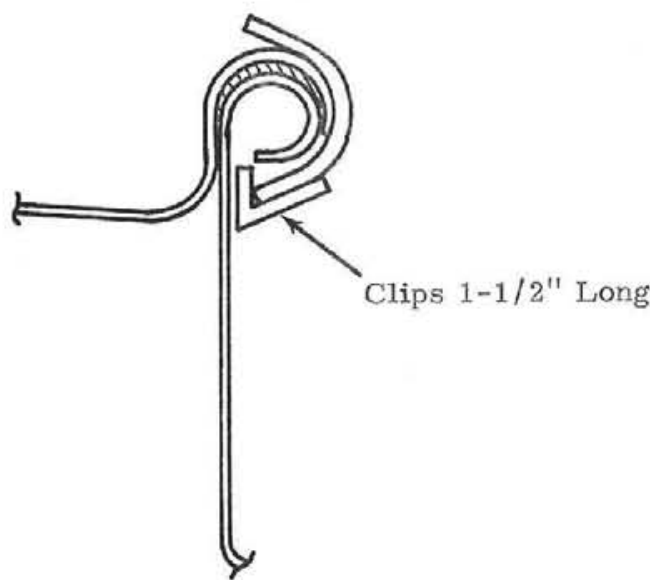

Figure 30, Clips Welded to Lock Ring

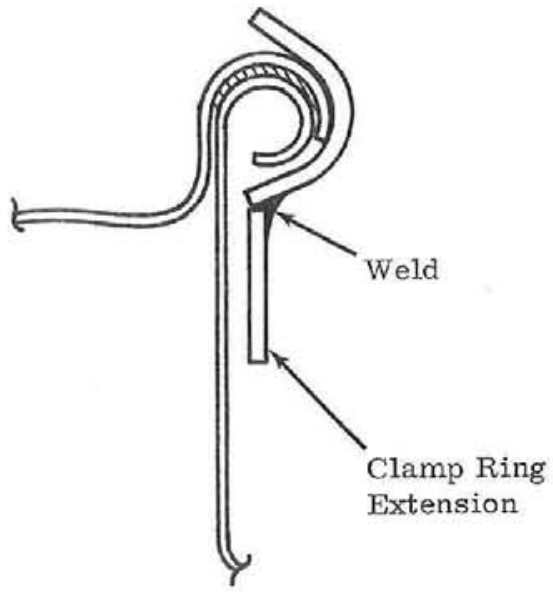

Figure 31. Extension of Lock Ring

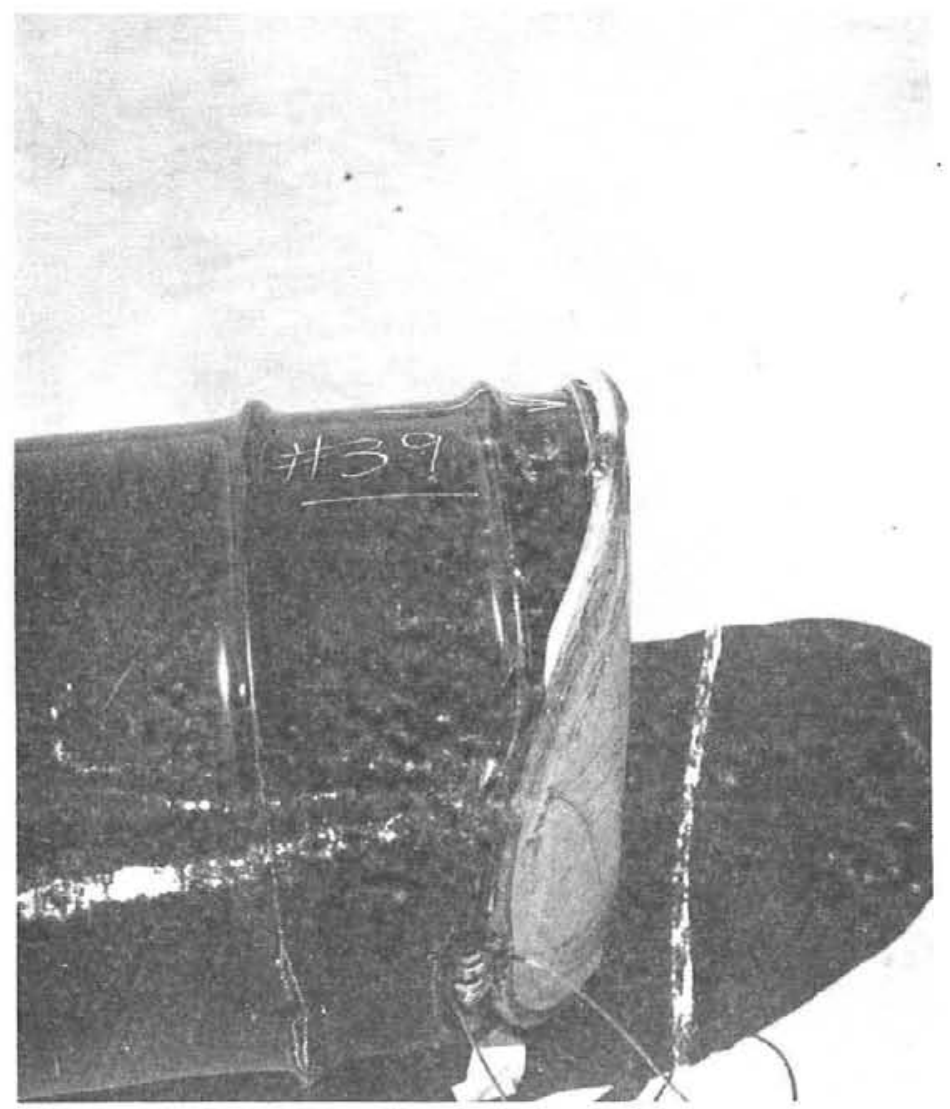

Figure 32. Posttest - 6 Clips Welded to Lock Ring - 800 Pounds at 30 Feet 

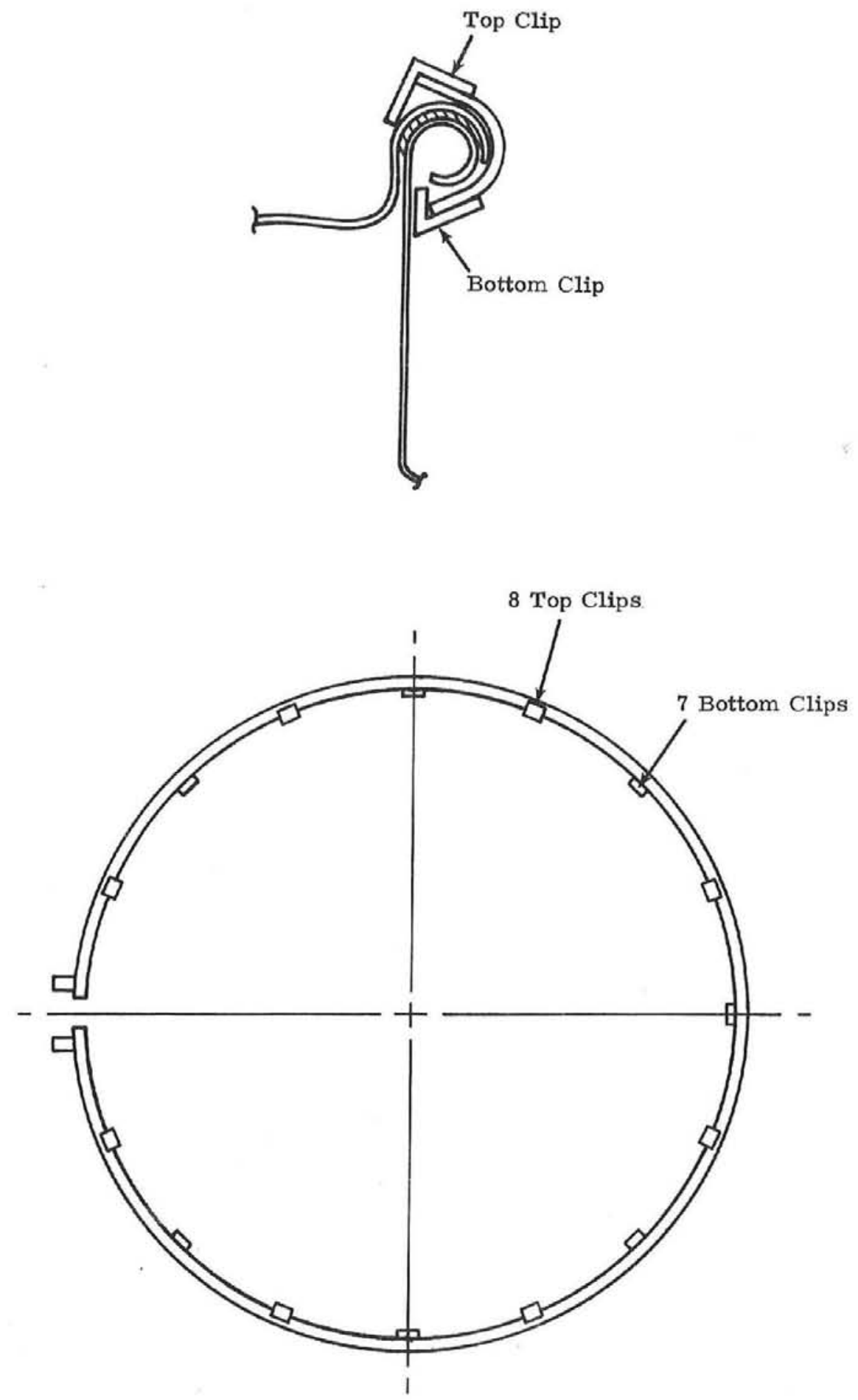

Figure 33. Details of Top and Bottom Clips Welded to Lock Ring 


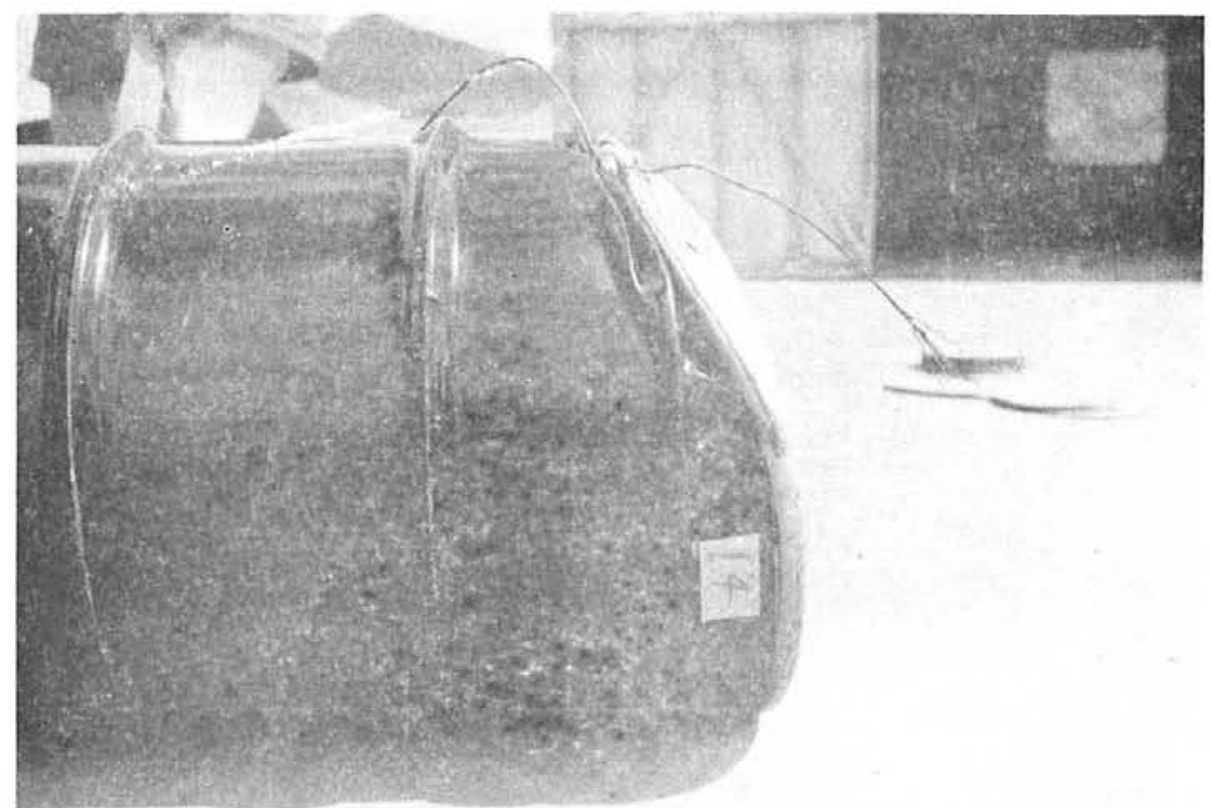

Figure 34. Pass with 8 Clips, Top and Bottom - 800 Pounds at 30 Feet

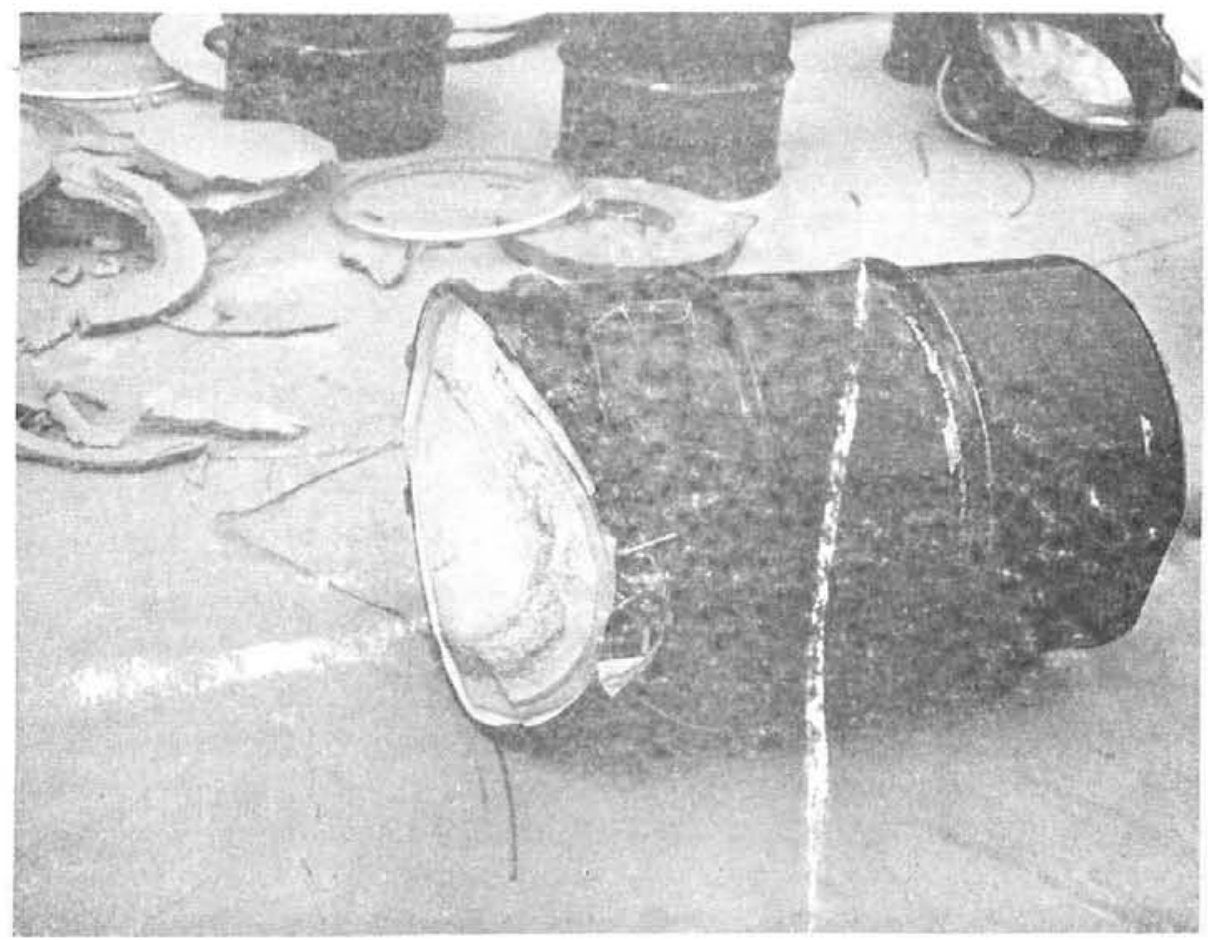

Figure 35. Marginal Pass with 8 Clips, Top and Bottom - 800 Pounds at 30 Feet 


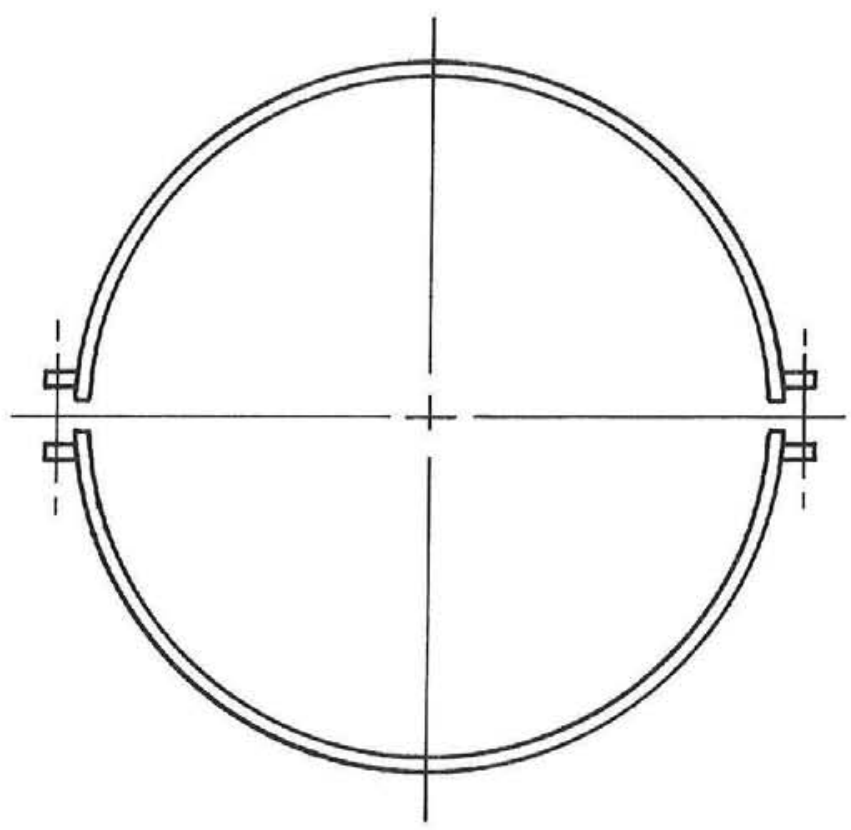

Figure 36. Half Ring Design

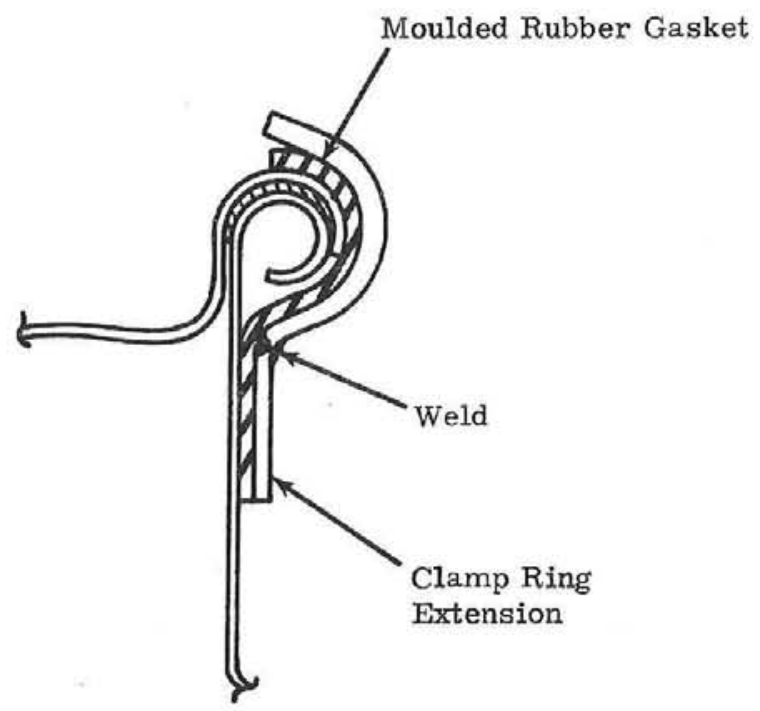

Figure 37. Sketch of Harry Fine Technique 


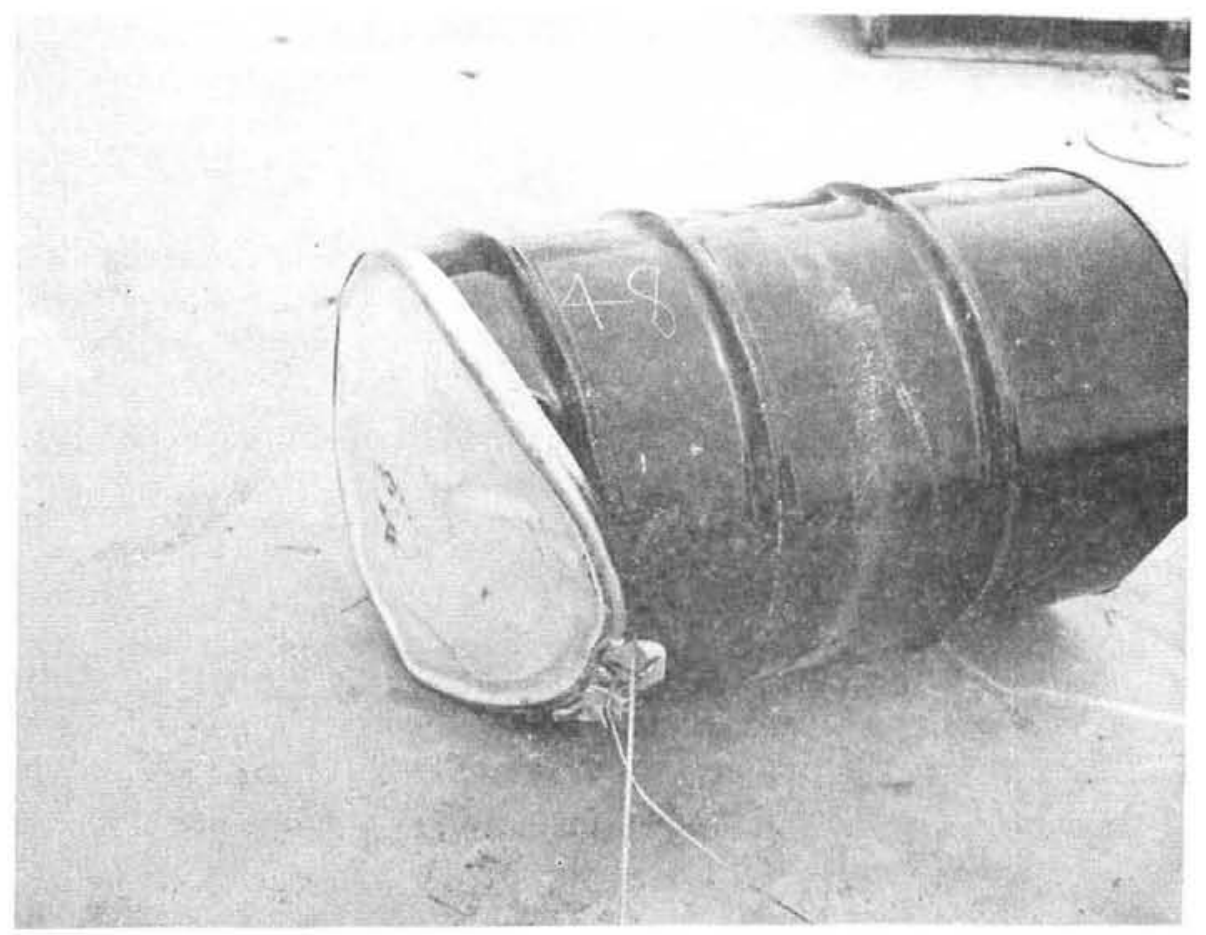

Figure 38. Posttest on Harry Fine Technique - 1000 Pounds at 30 Feet

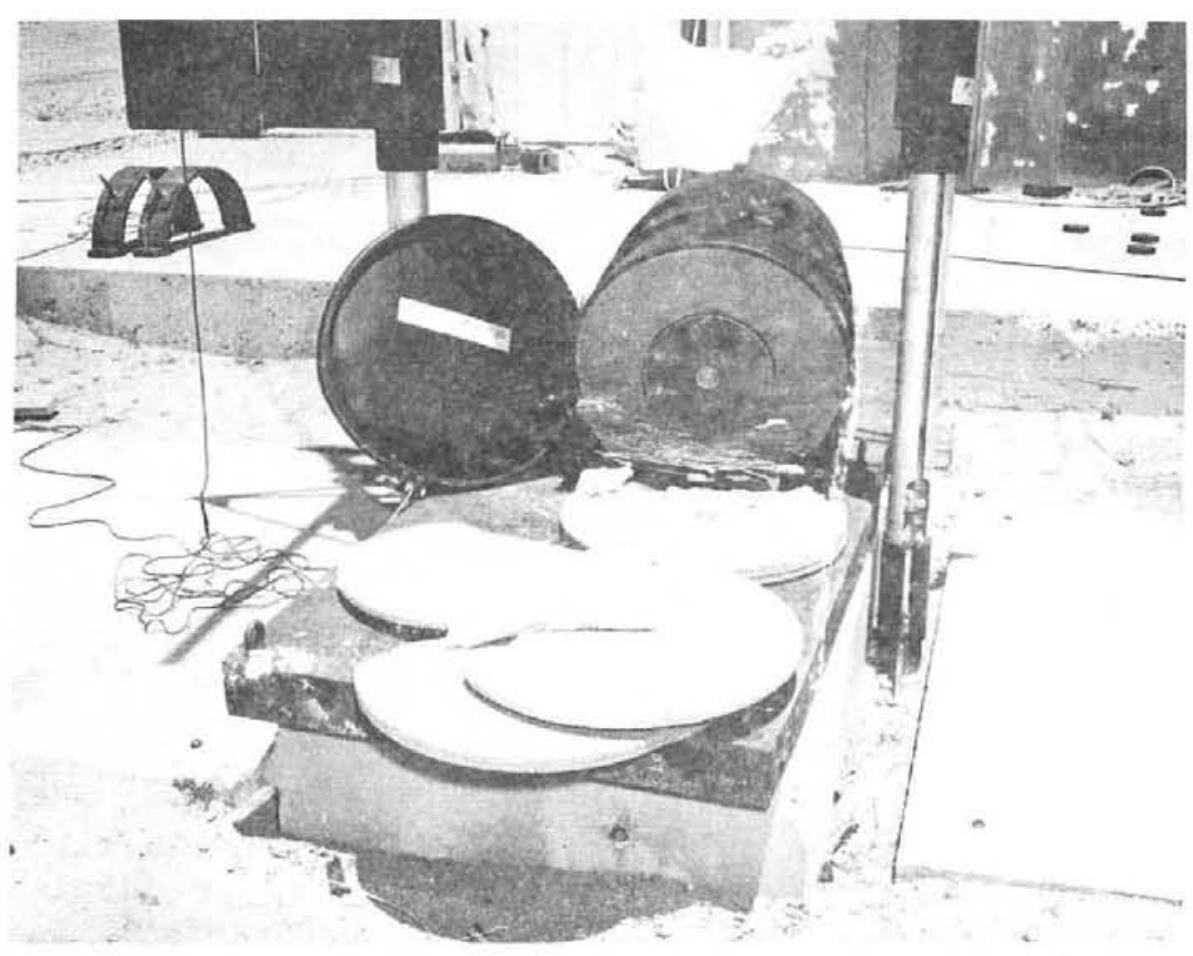

Figure 39. Posttest on MS27683-14 Container - 600 Pounds at 30 Feet 

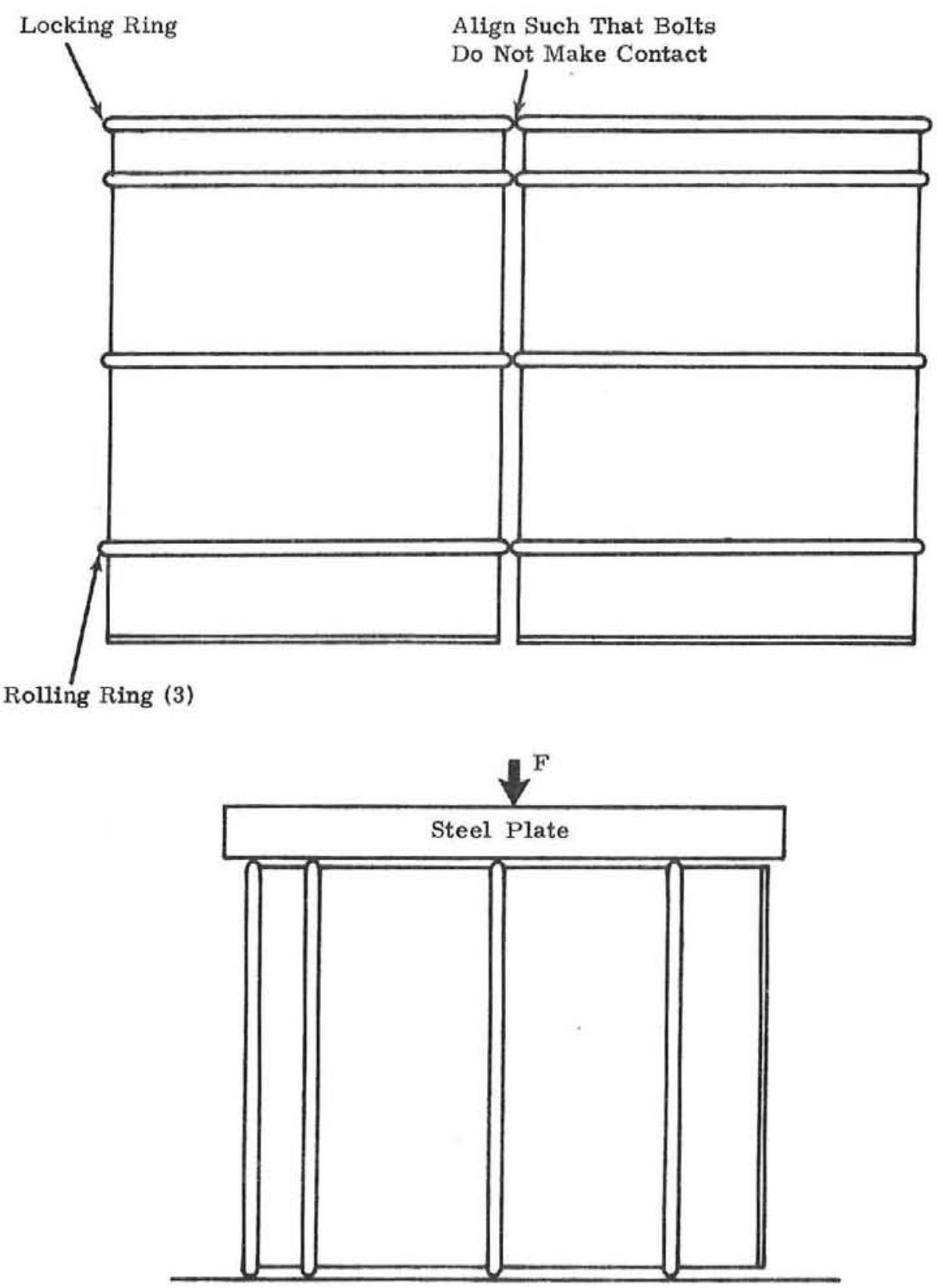

Figure 40. Container Load Configuration and Crush Test Simulation 


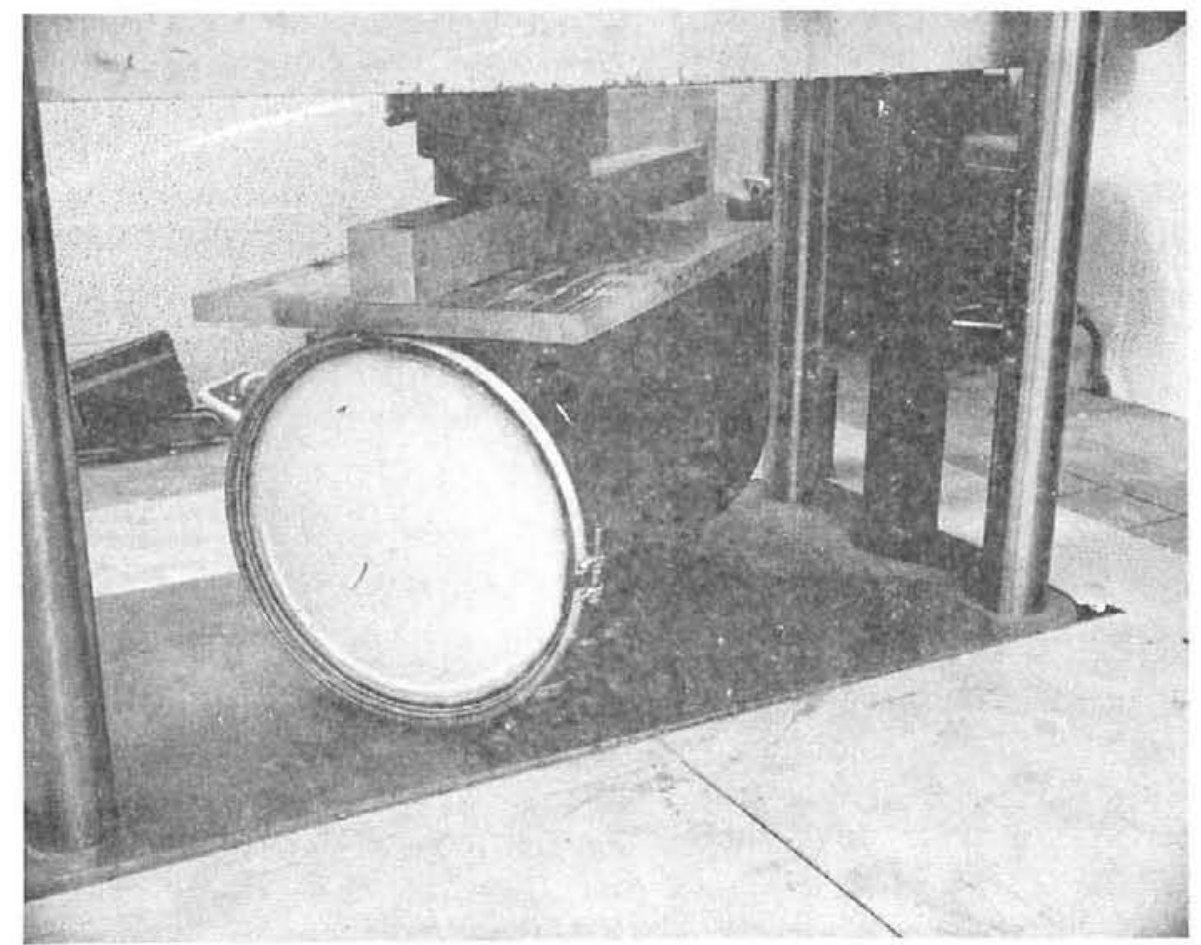

Figure 41. Crush Test Setup

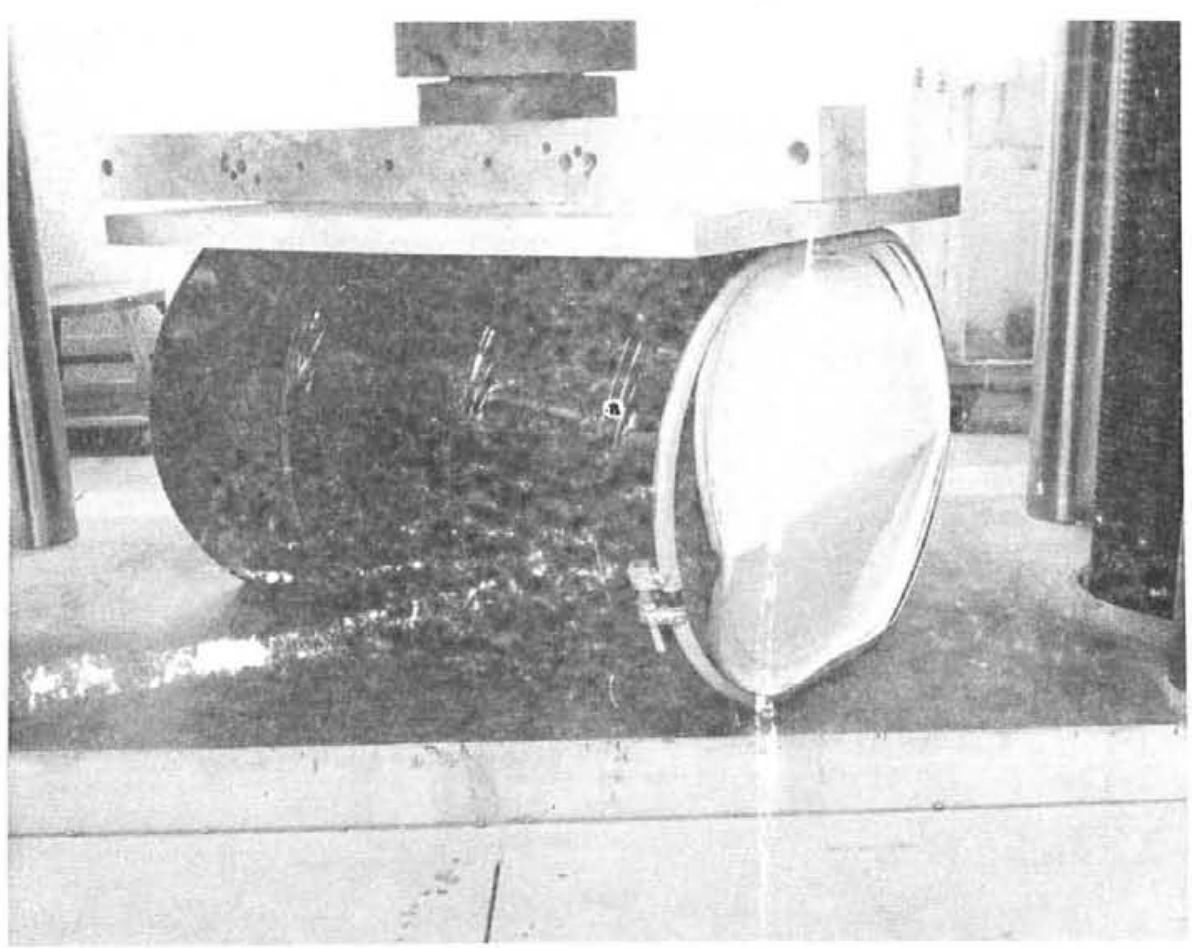

Figure 42. Failure of $17 \mathrm{C}$ Container Lid at 110,000 Pounds Static Load - Test 1 


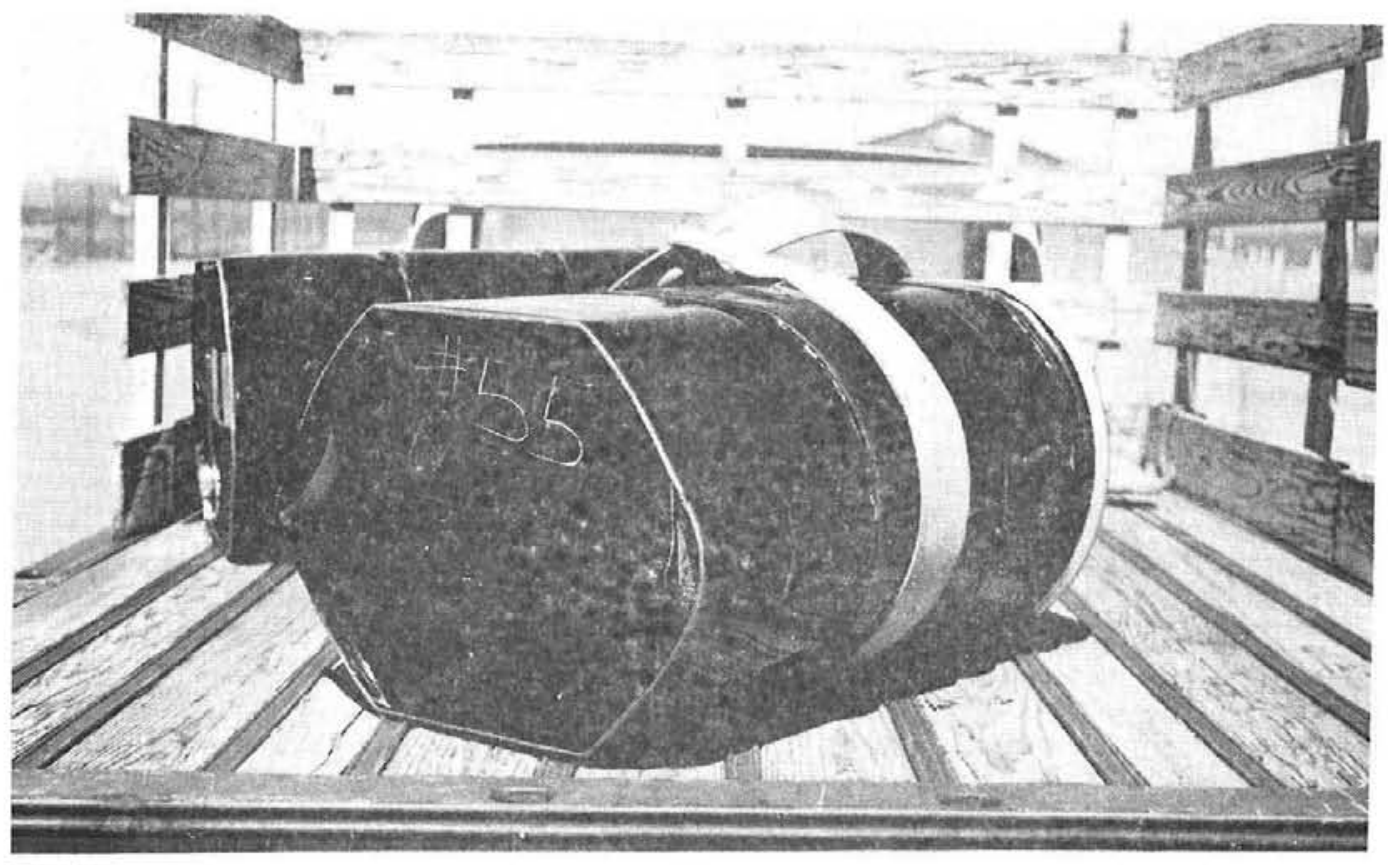

Figure 43. Failure of $17 \mathrm{C}$ Container Bottom at 120, 000 Pounds Static Load - Test 2

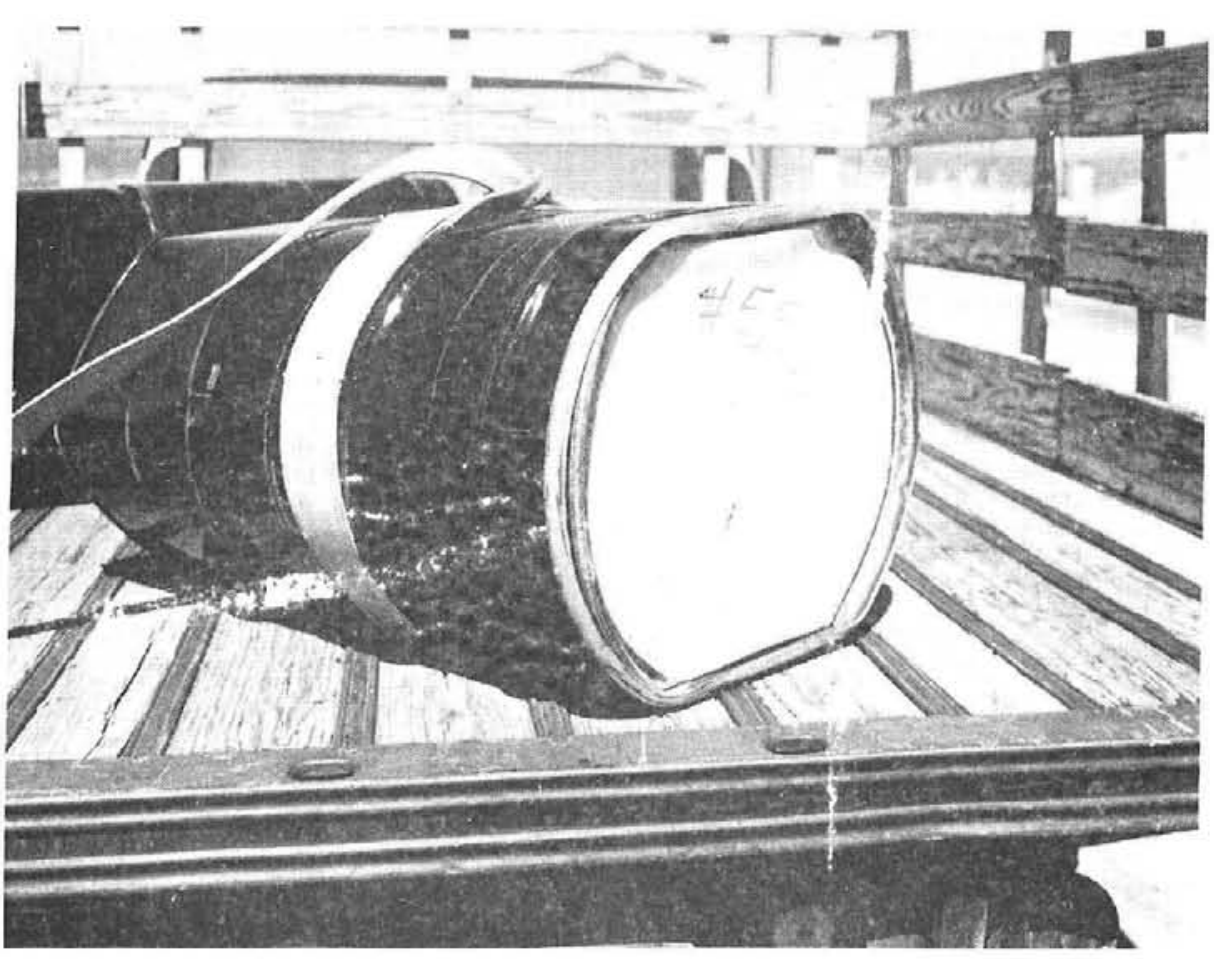

Figure 44. External View of Closure at 125, 000 Pounds - Test 2 


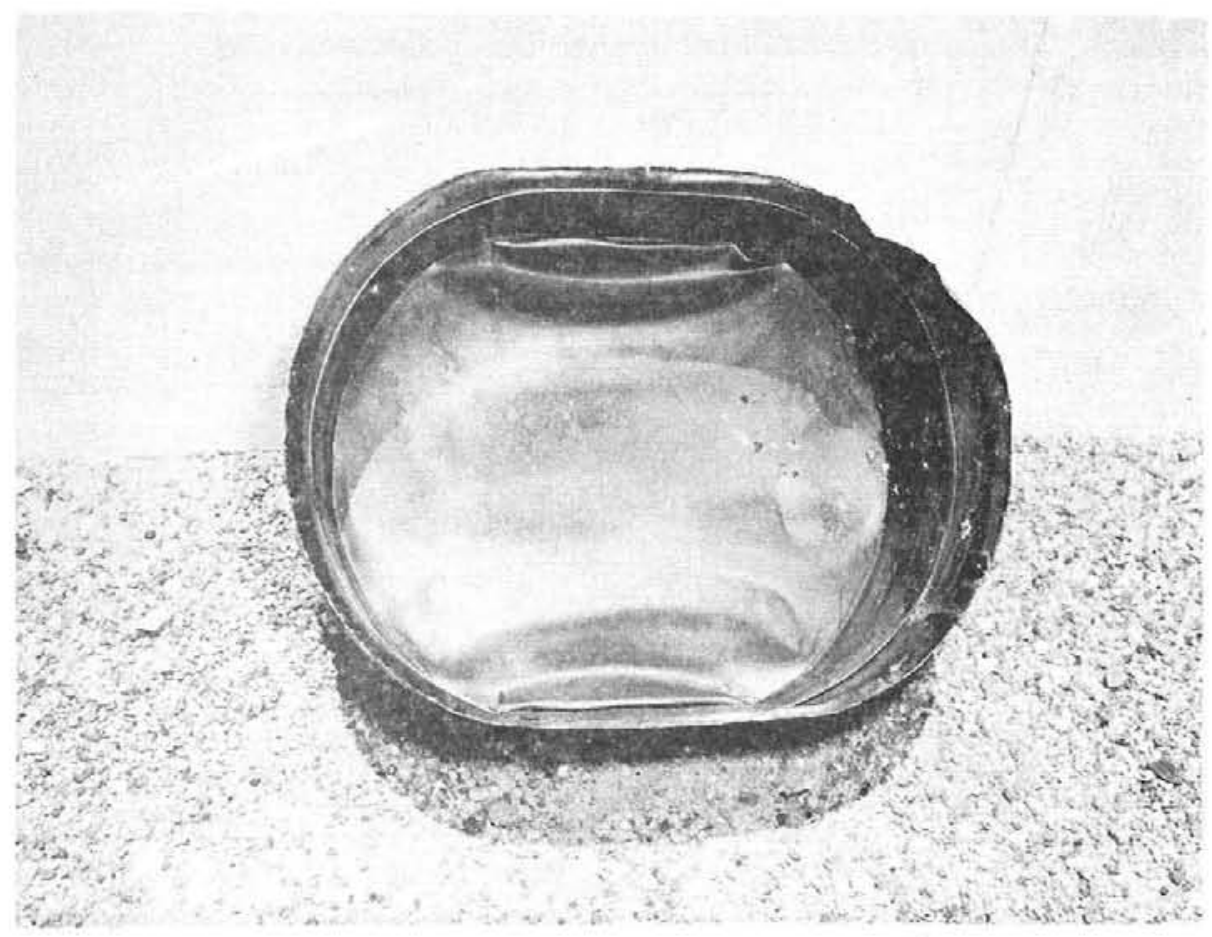

Figure 45. Internal View of Closure at 125,000 Pounds - Test 2

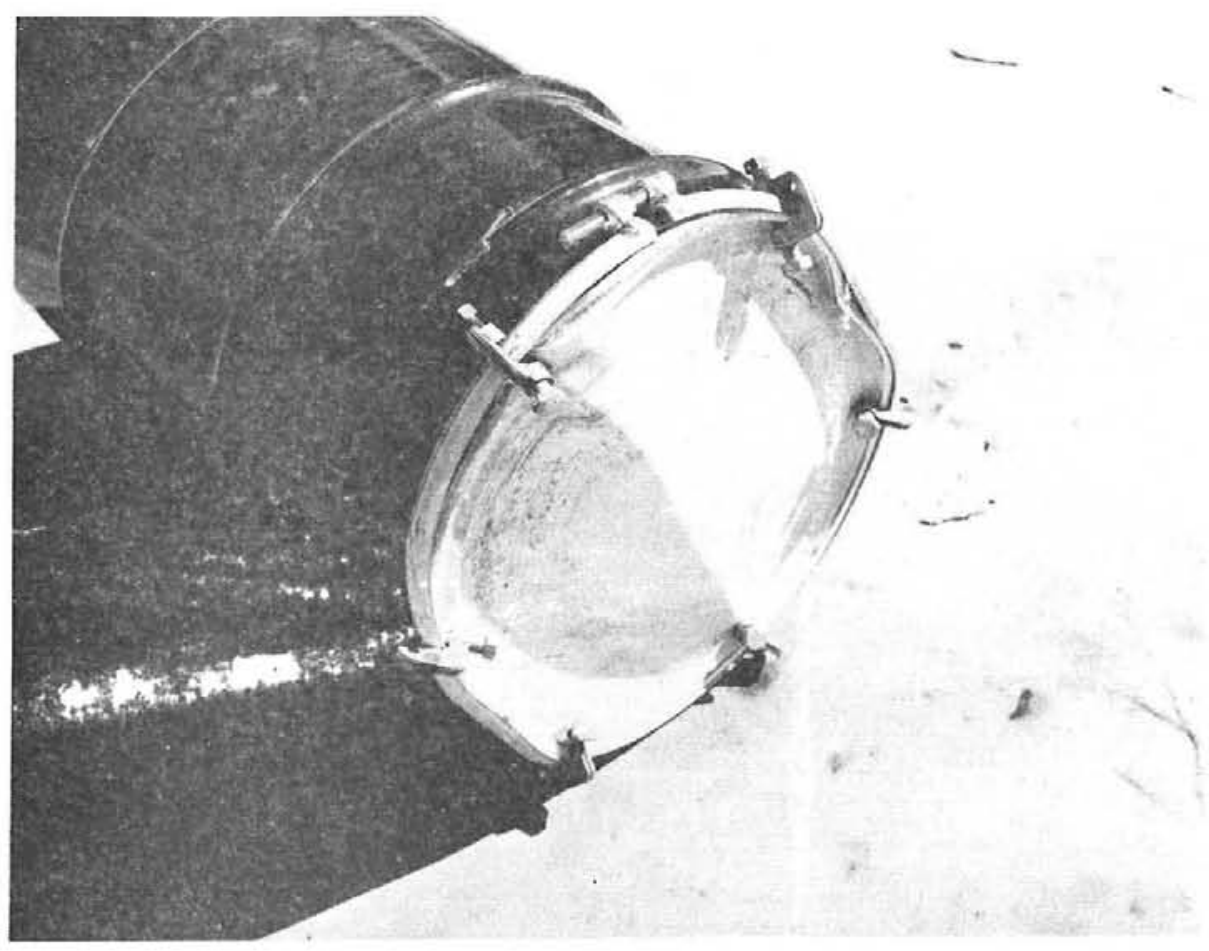

Figure 46. Failure of Closure at 105, 000 Pounds - Test 3 


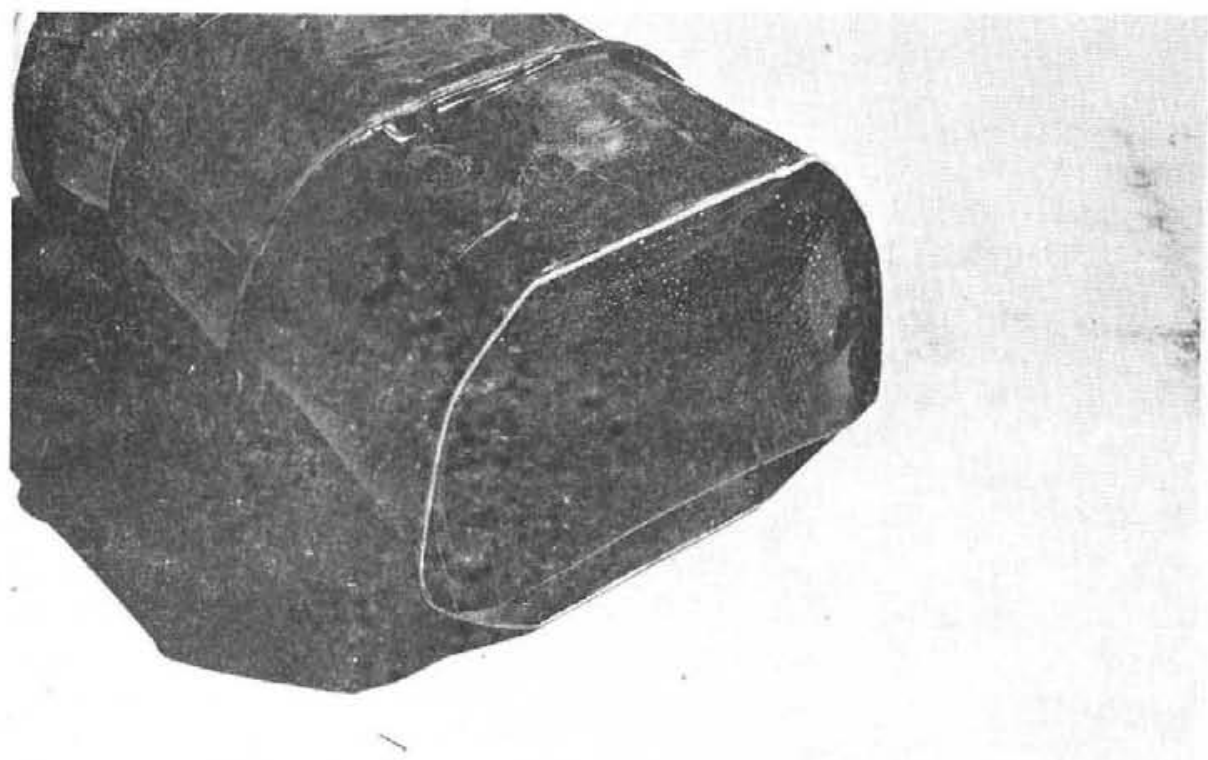

Figure 47. Failure of $17 \mathrm{C}$ Container Bottom at 120,000 Pounds - Test 4

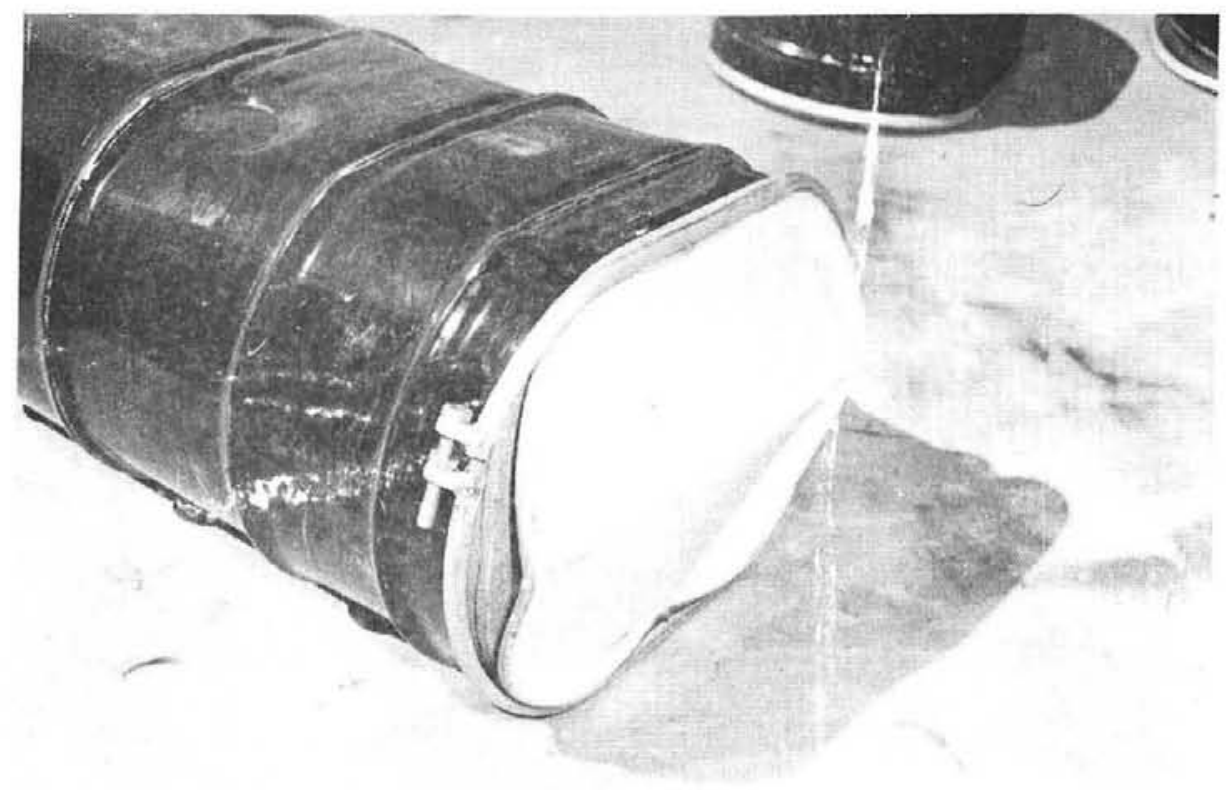

Figure 48. External View of Closure at 125, 000 Pounds - Test 4 


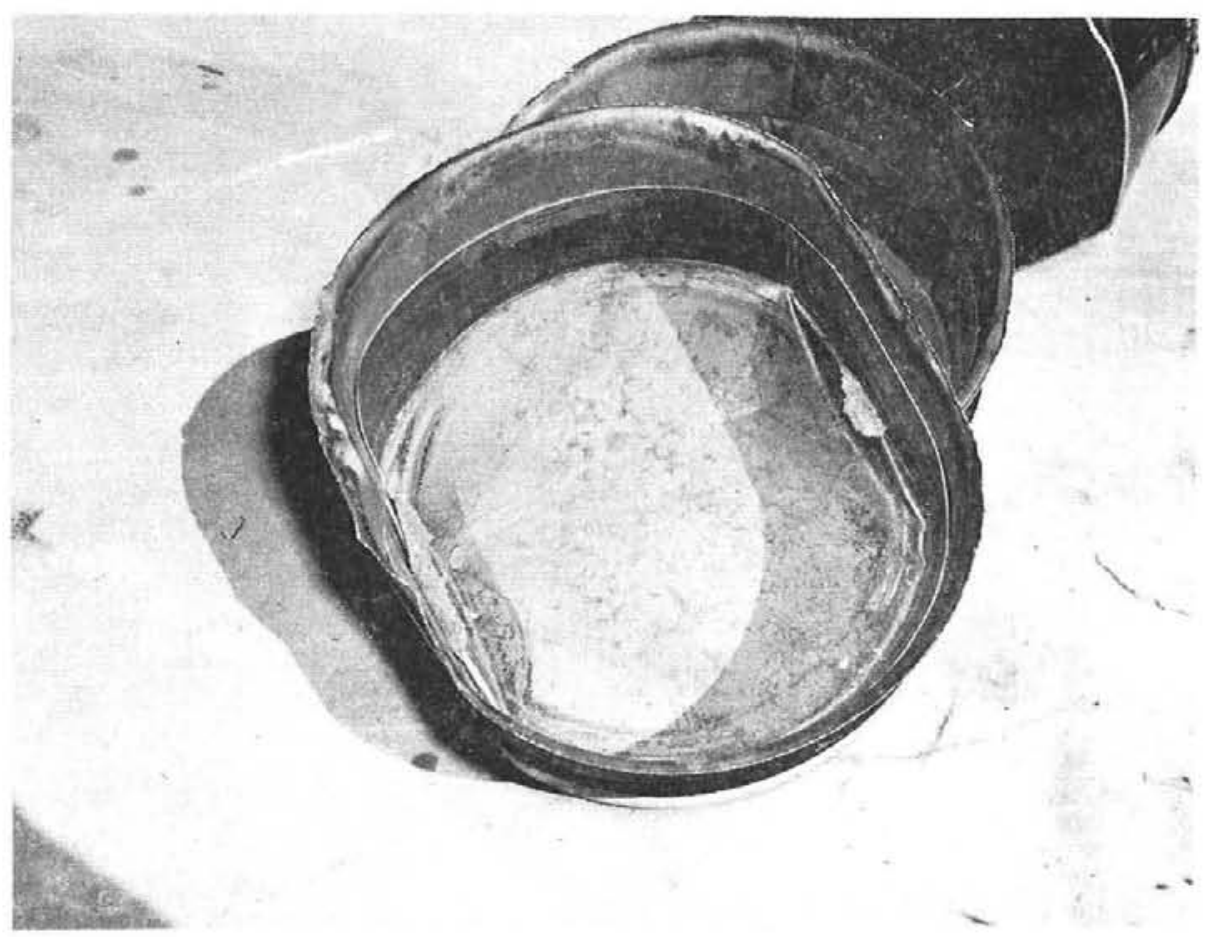

Figure 49. Internal View of Closure at 125, 000 Pounds - Test 4 
DISTRIBUTION:

TID-4500-R64, UC-71 (134)

US ERDA (2)

Savannah River Operations Office

P. O. Box A

Aiken, SC 29801

Attn: R. L. Chandler

W. G. O'Quinn

E. I. DuFont de Nemours and Company Savannah River Laboratory

Aiken, SC 29801

Attn: E. E. Lwallen

Oak Ridge National Laboratory

P. O. Box X

Oak Ridge TN 37830

Attn: L. B. Shappert

Battelle Memorial Institute (2)

Pacific Northwest Laboratory

P. O. Box 999

Richland, WA 99352

Attn: L. D. Williams

R. J. Hall

Battelle Memorial Institute (2)

Columbus Laboratories

505 King Avenue

Columbus, OH 43201

Attn: E. Lusk

R. A. Robinson

US Nuclear Regulatory Commission (4)

Washington, DC 20555

Attn: C. MacDonald

W. N. Lahs

R. Barker

R. Riggs

Nuclear and Loss Control Specialist (15)

American Insurance Association

85 John Street

New York, NY 10038

Attn: S. M. Fastman

For: N14 Committee ANSI

Harry Fine Associates, Inc.

Long Island, NY

Attn: H. Fine

Nuclear Engineering Company, Inc. 9200 Shelbyville Road, Suite 526

P. O. Box 7246

Louisville, KY 40207

Attn: K. Gablin

Los Alamos Scientific Laboratory (2)

P. O. Box 1663

Los Alamos, NM 87544

Attn: B. J. Donham

J. W. Nendecker, Jr.
Department of Transportation

Washington, DC 20590

Attn: A. W. Grella

E. I. DuPont de Nemours and Company

Wilmington, DE 19898

Attn: J. Langhear

US ERDA (50)

Environmental Control Technology Division Washington, DC 20545

A. Nides, President (5)

Steel Shipping Container Industries

2204 Morris Avenue

Union, NJ 07083

Rockwell International (2)

Rocky Flats Plant

P. O. Box 464

Golden, CO 80401

Attn: K. Terada

F. Adcock

Applied General Nuclear Services

P. O. Box 847

Bronwell, SC 29812

Attn: R. Peterson

US ERDA (8)

Albuquerque Operations Office

P. O. Box 5400

Albuquerque, NM 87115

Attn: J. N. Cook

D. K. Nowlin

D. Davis, Jr.

N. H. Mackay

US ERDA

Sandia Area Office

Albuquerque, NM 87115

Attn: R. R. Malone

V. V. Berniklan

E. Barraclough

R. Lowrey

T. B. Johnston

1281 S. W. Key

1282 T. G. Priddy

1283 H. C. Hardee

1284 R. T. Othmer

1710 V. E. Blake, Jr.

1713 J. T. Risse

1713 L. F. Stravasnik

1714 E. I. Bruce

5400 A. W. Snyder

5413 A. R. DeCharme, Jr,

5430 R. M. Jefferson

5432 J. K. Cole

5432 L. L. Bonzon (5)

5433 J. A. Andersen 
DISTRIBUTION: (Cont)

5443 D. R. Smith

9300 L. A. Hopkins, Jr.

9330 A. J. Clark, Jr.

9335 D. C. Bickel

9335 J. A. Lewin

9336 J. V. Otts (10)

8266 E. A. Aas (2)

3141 C. A. Pepmueller (Actg) (5)

3151 W. L. Garner (3)

For: ERDA/TIC (Unlimited Release) 